\title{
Characterization of air pollution control residues produced in a municipal solid waste incinerator in Portugal
}

\author{
Margarida J. Quina ${ }^{\mathrm{a}, *}$, Regina C. Santos ${ }^{\mathrm{b}}$, João C. Bordado ${ }^{\mathrm{c}}$, Rosa M. Quinta-Ferreira ${ }^{\mathrm{a}}$ \\ ${ }^{a}$ Group on Environment, Reaction and Separation Engineering (GERSE), Department of Chemical Engineering, \\ University of Coimbra, Polo II-Rua Sílvio Lima, 3030-790 Coimbra, Portugal \\ ${ }^{\mathrm{b}}$ Centro Tecnológico da Cerâmica e do Vidro, Ap. 8052, 3020-053 Coimbra, Portugal \\ ${ }^{c}$ Department of Chemical Engineering, Instituto Superior Técnico, Av. Rovisco Pais, 1049-001 Lisboa, Portugal
}

Received 16 March 2007; received in revised form 17 July 2007; accepted 18 July 2007

Available online 24 July 2007

\begin{abstract}
This study is mainly related with the physical and chemical characterization of a solid waste, produced in a municipal solid waste (MSW) incineration process, which is usually referred as air pollution control (APC) residue. The moisture content, loss on ignition (LOI), particle size distribution, density, porosity, specific surface area and morphology were the physical properties addressed here. At the chemical level, total elemental content (TC), total availability (TA) and the leaching behaviour with compliance tests were determined, as well as the acid neutralization capacity (ANC). The main mineralogical crystalline phases were identified, and the thermal behaviour of the APC residues is also shown. The experimental work involves several techniques such as laser diffraction spectrometry, mercury porosimetry, helium pycnometry, gas adsorption, flame atomic absorption spectrometry (FAAS), ion chromatography, scanning electron microscopy (SEM), X-ray fluorescence (XRF), X-ray diffraction (XRD) and simultaneous thermal analysis (STA). The results point out that the APC residues do not comply with regulations in force at the developed countries, and therefore the waste should be considered hazardous. Among the considered heavy metals, lead, zinc and chromium were identified as the most problematic ones, and their total elemental quantities are similar for several samples colleted in an industrial plant at different times. Moreover, the high amount of soluble salts $(\mathrm{NaCl}, \mathrm{KCl}$, calcium compounds) may constitute a major problem and should be taken into account for all management strategies. The solubility in water is very high (more than $24 \%$ for a solid/liquid ratio of 10 ) and thus the possible utilizations of this residue are very limited, creating difficulties also in the ordinary treatments, such as in solidification/stabilization with binders. (C) 2007 Elsevier B.V. All rights reserved.
\end{abstract}

Keywords: Characterization; APC residues; Incineration; Physical properties; Chemical properties

\section{Introduction}

The municipal solid waste incineration (MSWI) is a quite recent process in Portugal, with well-known advantages, such as significant volume and mass reduction, possibility of energy recovery and pathogenic destruction. However, when compared with other methods, the combustion processes have also the disadvantages of creating harmful solid wastes and large volume of toxic gaseous emissions. The composition of the solid residues produced during incineration depends mainly on the waste characteristics, the operating conditions in the combustion chamber and from the type of devices used for gaseous emissions control.

\footnotetext{
* Corresponding author. Tel.: +351 239798700 .

E-mail address: guida@eq.uc.pt (M.J. Quina).
}

In fact, the very restrictive gaseous emission limits established by the legislation are responsible for some of the particular characteristics of the APC residues, due to the required treatment of the gaseous effluents before being released into the atmosphere. The European legislation (Directive 2000/76/CE) set up limits for particulate matter, total organic carbon (TOC), $\mathrm{HCl}, \mathrm{HF}$, $\mathrm{SO}_{2}, \mathrm{NO}, \mathrm{NO}_{2}, \mathrm{CO}$, heavy metals ( $\mathrm{Sb}, \mathrm{As}, \mathrm{Pb}, \mathrm{Cr}, \mathrm{Co}, \mathrm{Cu}, \mathrm{Mn}$, $\mathrm{Ni}, \mathrm{V}, \mathrm{Cd}, \mathrm{Tl}$ and $\mathrm{Hg}$ ), dioxins and furans. The solid waste considered in this study comprehends then the fly ashes produced during the incineration process and carried over into the gaseous emissions as well as the additives used for controlling the atmospheric emissions (a slurry of lime and activated carbon used in scrubber units), and therefore a more appropriated designation is air pollution control (APC) residues. The addition of lime aims to neutralize the acid gases (mainly $\mathrm{HCl}, \mathrm{HF}$ and $\mathrm{SO}_{2}$ ) and the activated carbon is used in order to comply with the limits 
concerning $\mathrm{Hg}$, other volatile heavy metals and organic compounds (dioxins/furans) as well. According to European waste catalogue and hazardous waste list of European Union, the APC residues are considered as hazardous waste, with the reference $190107^{*}$. It should be noted that according to this list any waste marked with an asterisk $(*)$ is considered as a hazardous waste. The hazardous characteristics of this waste are mainly related with the high content of leachable heavy metals (e.g. $\mathrm{Pb}, \mathrm{Zn}, \mathrm{Cd}$, $\mathrm{Cr}, \mathrm{Cu}, \mathrm{Hg}$ ), soluble salts (e.g. $\mathrm{NaCl}, \mathrm{KCl}$, calcium salts) and toxic organic micro-pollutants (e.g. dioxins and furans) [1]. The APC residues must be treated before disposed of in landfills, in accordance with the corresponding environmental legislation. The current treatments can be grouped into three types: (i) separation of the potential toxic pollutants [2-7]; (ii) solidification/stabilization (S/S) treatment [8-13]; (iii) thermal treatments [14-18]. Some studies integrate different types of treatments by combining separation, $\mathrm{S} / \mathrm{S}$ and or thermal methods [19-21]. On the other hand, the utilization of incineration residues has been also considered under the concept of sustainability [22-28].

As stressed by Sawell et al. [29], for the development of the best options towards the management of the incinerations solid residues, it is absolutely necessary to characterize them and understand the factors which have major influence in their physical, chemical and mineralogical properties. In literature, the characterization of the solid wastes produced during the MSW incineration has been reported by a number of studies [1,30-42]. However, it is important to analyse which is the type of the solid waste that was considered in a particular study before using the corresponding data. In fact, in some cases it is not clear which industrial units contribute to the waste, being then difficult to use the described values. The solid wastes produced during the incineration of MSW that are more often studied are the bottom ashes [43-48], probably due to the several potential practical applications that are possible for this residue. Sometimes the bottom ashes, fly ashes and APC residues are considered in the same study [33-35,39,42,49-50]. In other cases, the characterization is only referred to the particles that are colleted in the electrostatic precipitators (ESP) [41,51], or in the scrubber units and fabric filters or other possible combinations [31,32,36-38,40,52-56].

Several of the parameters determined in the present study were also analysed in the literature, being the physical properties scarcer than the chemical characteristics. Some values related with moisture content, loss on ignition (LOI), particle size distribution, density, porosity, specific surface area are examples of the properties reported $[1,12,36,38,40,42,50,54,57,58]$. At chemical level, the total elemental content (TC), the total availability (TA), the acid neutralization capacity (ANC) and the leaching behaviour were frequently determined $[1,7,40,42,50,51,57,59-63]$. The morphology of APC residues was indicated in some references $[40,51,54,59]$, as well as the main mineralogical crystalline phases $[12,36,40,42,50,51,53,59,64-68]$ and the thermal behaviour $[36,56,68]$. The trace organic pollutants are also often analysed, namely in what concerns dioxins and furans [69-74]. A few studies established the relationship between the operating conditions and some of the characteristics of the residue [75,76].
The main goal of this study was the characterization of the APC residues produced in a mass burning process in Portugal, in order to handle safely and evaluate possible practical applications of such waste.

\section{Materials and methods}

Five composed samples of APC residues from MSW incineration were collected during more than 2 years in a Portuguese industrial plant, with the characteristics referred in Table 1 . The feed to the incinerator is mainly composed by household rubbish and some contribution of commercial waste similar to MSW, and in the area of the industrial incineration plant some paper, glass and plastic is recycled. The APC residues comprehend fly ashes from the economizer as well as solids produced in the semi-dry scrubbers (including $\mathrm{Ca}(\mathrm{OH})_{2}$ and activated carbon) and fabric filters. To reduce nitrous gases, ammonia is injected into the combustion chamber. For the neutralization of acid components, the removal of $\mathrm{Hg}$ and organics, a certain amount of calcium hydroxide and activated carbon is added into the scrubbing units. To ensure that the heterogeneity of the different samples that were colleted is minimised, the sampling procedure referred by the International Ash Working Group (IAWG) [1] was taken into account. The samples were taken from a screw downstream the storage silo, which accumulates the APC residues produced in the overall process, and plastic air-tight containers were used to store the samples. Each sample was collected by using a composed sampling strategy, collecting at least seven increments in order to obtain $10-20 \mathrm{~kg}$. The five samples were collected during two and a half years, starting in March of 2000, and will be referred in the next sections as A1-A5. At laboratorial level, small samples were obtained by using the strategies referred at the BS 3406-1, namely by using coning and quartering to obtain samples with about $1-2 \mathrm{~kg}$, and a rotating mechanical sampling device to obtain samples of about $100 \mathrm{~g}$. All the samples were stored into plastic containers, which were hermitically closed.

Table 1

Nominal parameters of the industrial MSW incinerator located in Portugal

\begin{tabular}{ll}
\hline Start up & 1999 \\
Operation & $24 \mathrm{~h} /$ day and 365 days/year \\
Type of process & Mass burning of MSW \\
Number of furnaces in parallel & 3 \\
Capacity & $28 \mathrm{t} / \mathrm{h}$ furnace or $2000 \mathrm{t} /$ day \\
Grate type & Detroit stoker reverse-acting stoker \\
Steam produced & $198000 \mathrm{~kg} / \mathrm{h}\left(52.8\right.$ bar at $\left.420{ }^{\circ} \mathrm{C}\right)$ \\
Electrical energy produced & $587 \mathrm{kWh} / \mathrm{t} \mathrm{MSW}$ \\
APC devices & Semi-dry scrubber + fabric filters \\
Solid wastes handling & Bottom ashes separated from other \\
& solid residues \\
Additives on scrubber units: & \\
$\quad$ Slurry of $\mathrm{Ca}(\mathrm{OH})_{2}$ & $8 \mathrm{~kg} / \mathrm{t} \mathrm{MSW}$ \\
$\quad$ Activated carbon & $460 \mathrm{~g} / \mathrm{t} \mathrm{MSW}$ \\
Control of $\mathrm{NO}_{x}$ with $\mathrm{NH}_{4} \mathrm{OH}$ & $789 \mathrm{~g} / \mathrm{t} \mathrm{MSW}$ \\
$\quad(\mathrm{SNCR})^{\mathrm{a}}$ & \\
Bottom ash & $\approx 300 \mathrm{~kg} / \mathrm{t} \mathrm{MSW}$ \\
APC residues & $\approx 40 \mathrm{~kg} / \mathrm{t} \mathrm{MSW}$ \\
\end{tabular}

a SNCR: selective non-catalytic reduction. 
The morphology was observed through scanning electron microscopy (SEM), Joel JSM-5310, for different magnifications. The moisture content was measured as soon as possible (the material has hygroscopic properties) by gravimetric method, using $2 \mathrm{~g}$ of material dried for $24 \mathrm{~h}$ at $105 \pm 5^{\circ} \mathrm{C}$. The LOI was determined as the weight loss after exposing the material in an open porcelain crucible at $550^{\circ} \mathrm{C}$ or $750{ }^{\circ} \mathrm{C}$ in a muffle furnace during $1 \mathrm{~h}$. The particle size distribution was obtained by using laser diffraction spectrometry (LDS)-Coulter LS 130 particle size analyzer. The analyses were performed by keeping the solid in a suspension of water with a few drops of a commercial solution, and in some experiments ultrasonic treatment was also used. The real density of the solid particles was determined by using helium picnometry, AccuPyc 1330-Micromeritics, based on the amount of displaced gas (helium). The samples were previously milled in order to disintegrate as much as possible the particles, so that the helium molecules were able to fulfil the tiniest pores. The specific surface area was examined by nitrogen adsorption, ASAP 2000-Micromeritics, being used the BET model (Brunauer-Emmett-Teller). The pore volume distribution of the particles was determined by mercury intrusion porosimetry, PoreSizer 9320-Micromeritics. The mercury pressure was increased from 0.5 to 1.5 psia to about 30,000 psia, and due to the size of mercury atoms macro- and some mesopores were characterized.

The total elemental composition (TC) of $\mathrm{Pb}, \mathrm{Cd}, \mathrm{Zn}, \mathrm{Cr}$, $\mathrm{Ni}, \mathrm{Cu}, \mathrm{K}, \mathrm{Na}, \mathrm{Ca}, \mathrm{Fe}, \mathrm{Al}$ and $\mathrm{Si}$ was determined by flame atomic absorption spectrometry (FAAS) (3300, Perkin-Elmer) after acid digestion. An air/acetylene flame was used for $\mathrm{Pb}, \mathrm{Cd}$, $\mathrm{Zn}, \mathrm{Cr}, \mathrm{Ni}, \mathrm{Cu}, \mathrm{K}, \mathrm{Na}, \mathrm{Ca}, \mathrm{Fe}$, and nitrous oxide/acetylene flame was selected for $\mathrm{Al}$ and $\mathrm{Si}$. The acid digestions were based on the Method 3052-USEPA, and representative samples of $0.4 \mathrm{~g}$ were digested in $12 \mathrm{~mL}$ of concentrated acids, in an acid digestion bomb (Parr 4744), which is a non-stirred pressure vessel with $45 \mathrm{~mL}$, equipped with a Teflon liner. The solid sample and the acid mixture within the bomb were heated in a conventional oven during $6 \mathrm{~h}$ at $150{ }^{\circ} \mathrm{C}$. Three concentrated acid mixture were tested: $\mathrm{HNO}_{3}$, aqua regia, $9 \mathrm{~mL} \mathrm{HNO}_{3}+3 \mathrm{~mL} \mathrm{HF}$, which will be further referred as TC1, TC2 and TC3. After an adequate cooling period, the vessel content was filtered through a $0.45 \mu \mathrm{m}$ pore membrane and diluted to $100 \mathrm{~mL}$ with demineralised water. When HF was used, a small amount of boric acid solution $(2.5 \%$ wt) was added [60]. The total mercury concentrations were determined by AMA-254 LECO, which allow the quantification of trace amounts of $\mathrm{Hg}$ in solid samples, by using direct combustion in high oxygen concentration atmosphere and a gold amalgamator for trapping all $\mathrm{Hg}$ from the gaseous phase. The detection system of $\mathrm{Hg}$ is based on atomic absorption spectrophotometry. Elemental analysis was performed, EA 1108 CHNS-O-Fisons, in order to obtain the amounts of $\mathrm{C}, \mathrm{H}, \mathrm{N}$ and $\mathrm{S}$ in the APC residues.

The total availability (TA) was determined according to the Dutch availability test (NEN 7341), which is often used for measuring the potential leachability of inorganic components from solid building (earthy and stony) and waste materials. This method requires two consecutive extractions with a liquid to solid ratio $(\mathrm{L} / \mathrm{S})$ of $50 \mathrm{~L} / \mathrm{kg}$ at $\mathrm{pH} 7$ and at $\mathrm{pH} 4$. In our case, some milling was necessary to comply with the statement that $95 \%$ of the material should have dimensions smaller than $125 \mu \mathrm{m}$. From the data obtained with this test the acid neutralization capacity (ANC) was estimated.

The leaching behaviour concerning compliance tests was determined throughout different protocols (DIN 38414-S4, TCLP, AFNOR X 31-210) being the test DIN 38414-S4 the mostly used in our study. Also in literature this protocol is often used for similar residues $[39,42]$. This is a German standard batch leaching test established to determine the leaching of sediments and sludges, also applicable to solids [77]. The test is carry out at $\mathrm{L} / \mathrm{S}=10$, by shaking the suspension for $24 \mathrm{~h}$ with demineralised water. In the leaching solutions, $\mathrm{pH}$, conductivity, total dissolved solids (TDS), as well as several elements ( $\mathrm{Pb}, \mathrm{Cd}$, $\mathrm{Zn}, \mathrm{Cr}, \mathrm{Ni}, \mathrm{Cu}, \mathrm{Hg}, \mathrm{K}, \mathrm{Na}, \mathrm{Ca}), \mathrm{Cl}^{-}$and $\mathrm{SO}_{4}{ }^{2-}$ were measured. The TDS was determined according to NF T 90-029, which is a French standard commonly used for this purpose. The toxicity characteristic leaching procedure (TCLP) is a batch method established by USEPA in 1990, usually referred as the Method 1311. In this case, the liquid to solid ratio $(\mathrm{L} / \mathrm{S})$ is $20 \mathrm{~L} / \mathrm{kg}$ and an agitation period of $18 \mathrm{~h}$ is used. According to the alkalinity of the solid in our case a solution obtained with acetic acid with pH 2.88 was used. The AFNOR X 31-210 is a French standard method, which comprehends a batch leaching test with $\mathrm{L} / \mathrm{S}=10 \mathrm{~L} / \mathrm{kg}$ and a shaking period of $24 \mathrm{~h}$. The ANC was estimated based on the availability tests (NEN 7341) by taking into account the quantities of nitric acid used for $\mathrm{pH}$ control at 7 and 4. The concentration of chloride and sulphate anions was determined by ion chromatography, Action Analyser-Waters, using a $100 \mu \mathrm{L}$ sample loop. However, due to the high concentration of the chloride ions, in some cases this technique did not permit to determine sulphates since the peak was not detected. On the other hand, the analysis through ion chromatography is a timeconsuming technique, mainly due to calibration procedures and the long retention times required. Therefore, in some cases the silver nitrate titration method was used in order to provide faster measurements. The total organic carbon (TOC) dissolved was determined, TOC 5000A-Shimadzu, by subtracting the inorganic value from the total carbon value. X-ray fluorescence (XRF), PW1480-Philips, was only used in a qualitative way.

The mineralogical crystalline phases were identified through powder X-ray diffraction (XRD), PW1710-Philips, with a $\mathrm{Cu}$ $\mathrm{K} \alpha$ radiation $(40 \mathrm{kVe}$ and $30 \mathrm{~mA}$ ), and the minerals were recognized according to the data base ICDD (International centre for diffraction data). The thermal behaviour of the APC residues was obtained by using simultaneous thermal analysis (STA), STA 449C-Netzsch, with a heating rate of $10^{\circ} \mathrm{C} / \mathrm{min}$ in air. For this analysis sub-samples were previously milled to less than $75 \mu \mathrm{m}$, and about 20-30 mg were used.

\section{Results and discussion}

This study is centred on the characterization of five representative samples of air pollution control (APC) residues, collected in a Portuguese municipal solid waste incineration (MSWI) process. The work involved morphological analyses, physical and chemical characterization, mineralogical investigation and ther- 

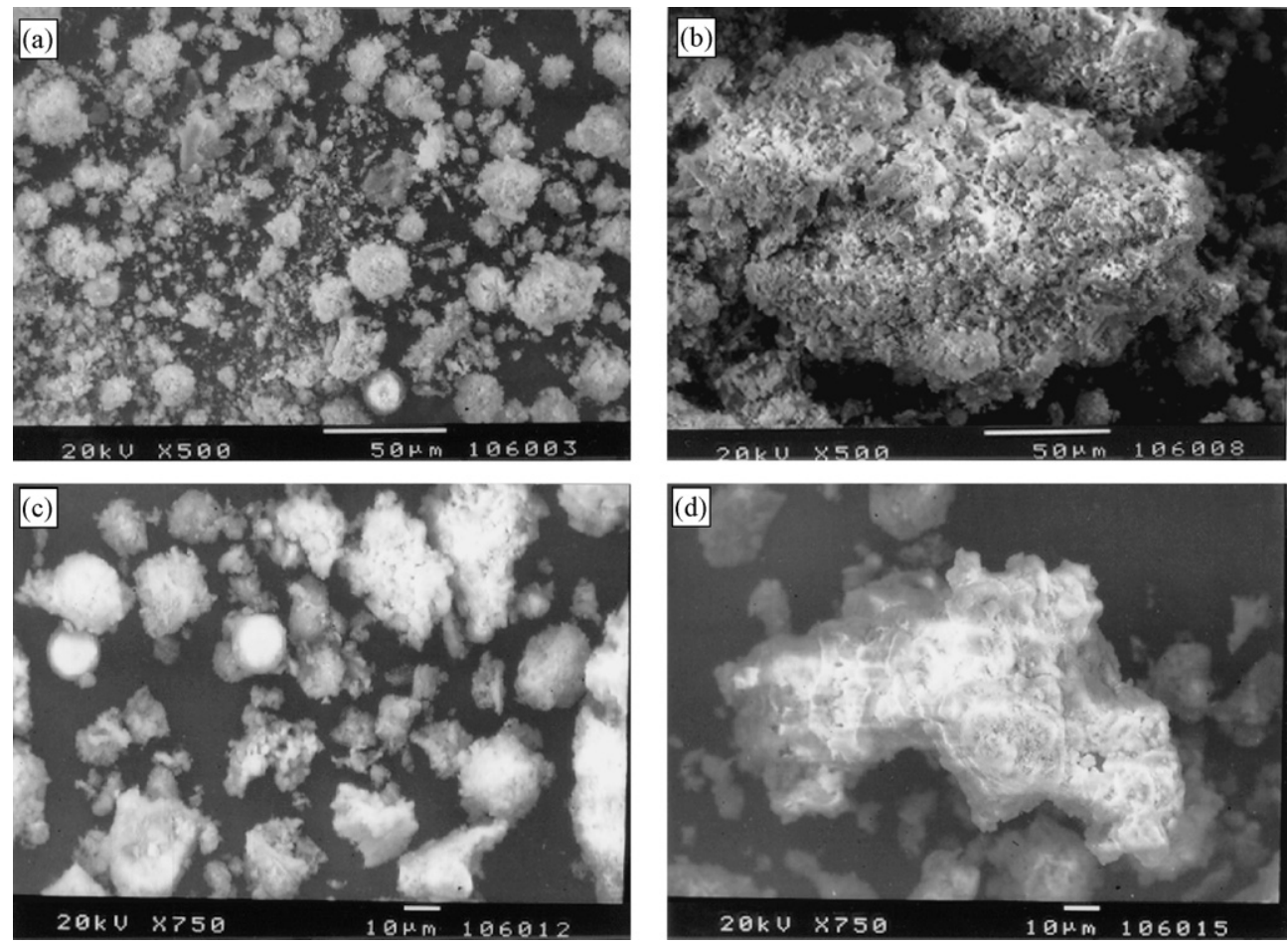

Fig. 1. SEM pictures of (a)-(b) APC residues and (c)-(d) washed APC residues.

mal analysis. The characterization of APC residues is essential for evaluating the most adequate management strategy to protect environment.

\subsection{Morphology}

By visual observation, the APC residues are characterized by a white to ash grey colour, which results from a mixture of fly ashes (produced in the combustion chamber) and high quantity of calcium hydroxide and activated carbon (added in the scrubber units). The morphology of APC residues was evaluated by scanning electron microscopy (SEM), and Fig. 1(a) and (b) illustrates some pictures of the waste as it was collected in the plant (without any treatment), and Fig. 1(c) and (d) shows images after the APC residues were washed with distilled water (agitation during $24 \mathrm{~h}$ ). It can be seen that the APC residues are a fine particulate material, composed by a broad range of sizes, with rough surfaces as a result from the condensation processes during the decreasing of the gaseous temperature. In spite of the complexity of shapes, two types of particles can be observed: spherical particles (constituted by aluminosilicates) and polycrystalline platelets. Fig. 1(b) shows a polycrystalline particle where it is possible to observe that this type of particles exhibits a high porosity (high specific surface area), with pores smaller than $10 \mu \mathrm{m}$. Fig. 1(c) clearly illustrates that after the contact of the residue with water, spherical particles are more evident, due to the dissolution of soluble salts from their surface. The morphology of similar residues may be found in other studies $[1,40,50,51,54,59]$. According to the International Ash Working Group (IAWG), the APC residues may be composed by five types of particles: fused spheres, crystalline, polycrys- talline, opaque and char, and the most common ones are the polycrystalline and opaque irregular shaped particles.

\subsection{Physical characterization}

In literature less attention has been focused on physical characterization than to chemical properties. In this study, moisture content, loss on ignition (LOI), particle size distribution, density or true specific gravity, porosity and specific surface area were investigated.

The moisture content $(H)$ depends mainly on the industrial equipment units that contribute for the final waste, which are in our case the combustion chamber, semi-dry scrubbing units and fabric filters. In Table 2 the moisture content for the five samples (A1-A5) are indicated, as well as the confidence interval (CI) at a significance of $95 \%$ and the number of sub-samples analysed $(n)$. The mean value for this parameter is about $0.86 \%$, which is similar to other values indicated in the literature [36,78]. 0 According to the procedure indicated in the EURACHEM Guide for "Quantifying Uncertainty in Analytical Measurement" [79] the expanded uncertainty associated to a measurement of moisture content for this material is about $\pm 0.014 \%$ (with a coverage factor $k=2$ ). Since the residue contains hygroscopic phases, such as calcium salts, the moisture content may vary with time, being therefore required that the samples should be stored in laboratory in air-tight containers.

The loss on ignition (LOI) was determined for APC residues as the weight loss when sub-samples are kept at 550 and $750^{\circ} \mathrm{C}$, and the results obtained are indicated in Table 2 . At $550^{\circ} \mathrm{C}$ the weight decrease was $1.6 \%$ in average, which may be related with the loss of structural water, organic matter and activated carbon. 
Table 2

Moisture content $(H)$ and loss on ignition (LOI) for five samples

\begin{tabular}{|c|c|c|c|c|c|c|c|c|c|}
\hline \multirow[t]{2}{*}{ Sample } & \multicolumn{3}{|c|}{ Moisture content } & \multicolumn{3}{|c|}{ LOI at $550^{\circ} \mathrm{C}$} & \multicolumn{3}{|c|}{ LOI at $750^{\circ} \mathrm{C}$} \\
\hline & $H(\%)$ & CI (95\%) & $n$ & LOI $(\%)$ & CI (95\%) & $n$ & LOI (\%) & CI (95\%) & $n$ \\
\hline A1 & 1.05 & \pm 0.26 & 4 & 1.16 & \pm 0.67 & 5 & 10.41 & \pm 0.35 & 5 \\
\hline A3 & 0.82 & \pm 0.39 & 4 & 1.49 & \pm 0.41 & 5 & 8.66 & \pm 0.61 & 4 \\
\hline A4 & 0.85 & \pm 0.08 & 6 & 2.03 & \pm 0.22 & 3 & 7.58 & \pm 0.23 & 6 \\
\hline A5 & 0.73 & \pm 0.11 & 5 & 1.93 & \pm 0.10 & 3 & 7.01 & \pm 0.14 & 5 \\
\hline
\end{tabular}

The LOI corresponding to the further temperature increment up to $750{ }^{\circ} \mathrm{C}$ may be attributed to $\mathrm{CO}_{2}$ and $\mathrm{HCl}$ release, as a result of the thermal decomposition of the $\mathrm{CaCO}_{3}$ and $\mathrm{CaOHCl}$ into $\mathrm{CaO}$. As a consequence, the average of the overall weight loss calculated at $750{ }^{\circ} \mathrm{C}$ was $8.39 \%$.

The particle size distribution for samples A1-A5 were determined by laser diffraction spectrometry, after an adequate amount of sample was suspended in water. The analysis were done either without ultrasonic treatment or with 1 min of ultrasonic treatment, and the results obtained for mean diameter and for median are presented in Table 3. The volume of the particles was measured by this technique, and therefore the mean and median values were determined based on this property. The distributions of the particle size diameters are characterized by mean diameters in the range of 159-244 $\mu \mathrm{m}$, but if 1 min of ultrasonic treatment was used, these values decreased to $44-189 \mu \mathrm{m}$. Fig. 2 shows the results obtained in our study for the differential particle size distributions for five samples, without treatment (in (a)) and with $1 \mathrm{~min}$ of ultrasonic treatment (in (b)). In all the cases (even after ultrasonic treatment) more than one maximum is evident which may indicate that the distributions are at least bimodal. In Fig. 3(a) and (b) the cumulative particle size distributions without and with 1 min of ultrasonic treatment are represented, being marked the ranges concerning the median diameters. Figs. 2 and 3 clearly show that the ultrasonic treatment decreases the particle diameters, which may indicate that the particles are originally agglomerated or can be dissolved as a consequence of ultrasounds. In the literature, some studies indicate data concerning particle size dis-
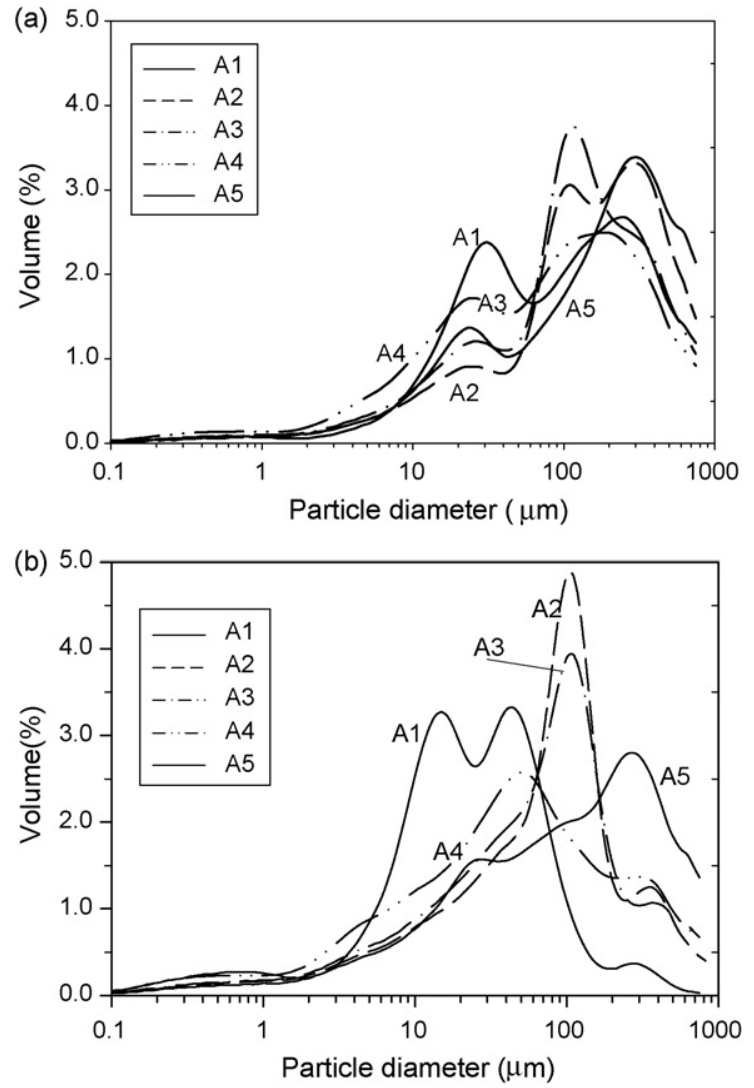

Fig. 2. Differential particle size distributions (based on volume) for samples A1-A5: (a) without treatment and (b) with 1 min of ultrasonic treatment.

Table 3

Physical properties for samples A1-A5

\begin{tabular}{|c|c|c|c|c|c|c|c|}
\hline & Units & A1 & $\mathrm{A} 2$ & A3 & A4 & A5 & Mean \\
\hline \multicolumn{8}{|l|}{ Mean diameter based on volume } \\
\hline Without ultrasonic treatment & \multirow{2}{*}{$\mu \mathrm{m}$} & 179 & 226 & 186 & 159 & 244 & 199 \\
\hline With 1 min ultrasonic treatment & & 44 & 124 & 125 & 115 & 189 & 119 \\
\hline \multicolumn{8}{|l|}{ Median diameter based on volume } \\
\hline Without ultrasonic treatment & \multirow{2}{*}{$\mu \mathrm{m}$} & 103 & 160 & 123 & 88 & 183 & 131 \\
\hline With 1 min ultrasonic treatment & & 24 & 86 & 77 & 47 & 110 & 69 \\
\hline True specific gravity & $\mathrm{g} / \mathrm{cm}^{3}$ & 2.50 & 2.52 & 2.57 & 2.55 & 2.50 & 2.53 \\
\hline Specific surface area-BET & $\mathrm{m}^{2} / \mathrm{g}$ & 6.29 & 5.85 & 6.77 & 5.77 & 4.94 & 5.92 \\
\hline Bulk density & $\mathrm{g} / \mathrm{cm}^{3}$ & 0.71 & 0.67 & 0.69 & 0.71 & 0.66 & 0.69 \\
\hline Skeletal density & $\mathrm{g} / \mathrm{cm}^{3}$ & 2.09 & 2.11 & 2.01 & 1.95 & 1.80 & 1.99 \\
\hline Total porosity (inter and intraparticular) & $\%$ & 65.8 & 68.4 & 65.5 & 63.4 & 63.4 & 65.3 \\
\hline Open porosity of the particles & $\%$ & 48.2 & 51.3 & 48.3 & 53.2 & 47.1 & 49.6 \\
\hline Total particle porosity & $\%$ & 56.8 & 59.2 & 59.3 & 64.2 & 62.0 & 60.4 \\
\hline
\end{tabular}



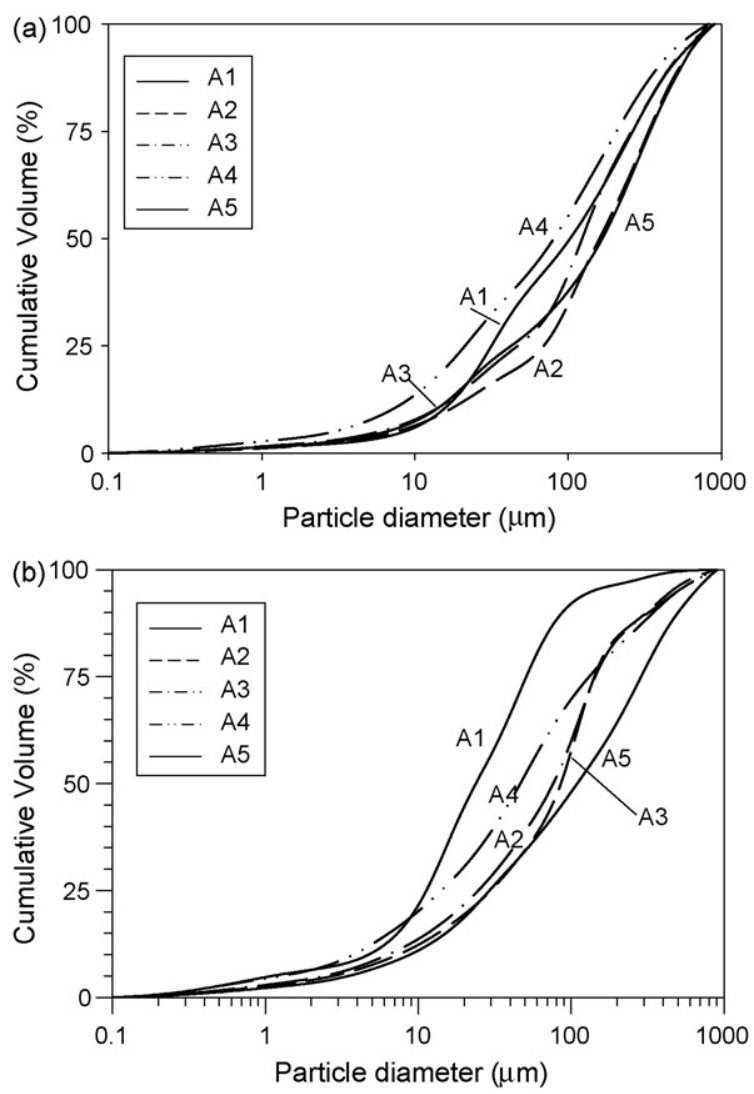

Fig. 3. Cumulative particle size distributions (based on volume) for samples A1-A5: (a) without treatment and (b) with 1 min of ultrasonic treatment.

tribution $[1,38,40,42,54,55,57,58]$ and some of them also refer the possibility of bimodal distributions $[38,42,54]$.

The true density or specific gravity is defined by weight of a given sample volume, considering that the material did not have closed porosity. The obtained values are shown in Table 3 , and it can be concluded that this property is within a narrow range for all samples, with a mean value of $2.53 \mathrm{~g} / \mathrm{cm}^{3}$. Identical results may be found in literature for similar residues [20].

The specific surface area was obtained by nitrogen adsorption measurements, considering the BET model. The results are indicated in Table 3, where one can observe that the specific surface area is in the range of $4.94-6.77 \mathrm{~m}^{2} / \mathrm{g}$, with a mean value of $5.92 \mathrm{~m}^{2} / \mathrm{g}$. Comparable values are also indicated in the literature for the same type of residues $[1,20,78]$.

The particles porosity distributions determined through mercury intrusion porosimetry were indicated in Fig. 4, concerning differential and the cumulative curves, respectively. From these results, one may state that the volume of $\mathrm{Hg}$ related with pore diameters less than $7 \mu \mathrm{m}$ may correspond to intraparticle volumes. By taking this into account the values for the different characteristics are shown in Table 3 (for samples A1-A5). The open porosity of the particles is close to $50 \%$ for all samples, and the total porosity has a mean value of $60 \%$.

\subsection{Chemical characterization}

In literature a lot of data may be found concerning chemical characteristics of the APC residues. In general, the waste is

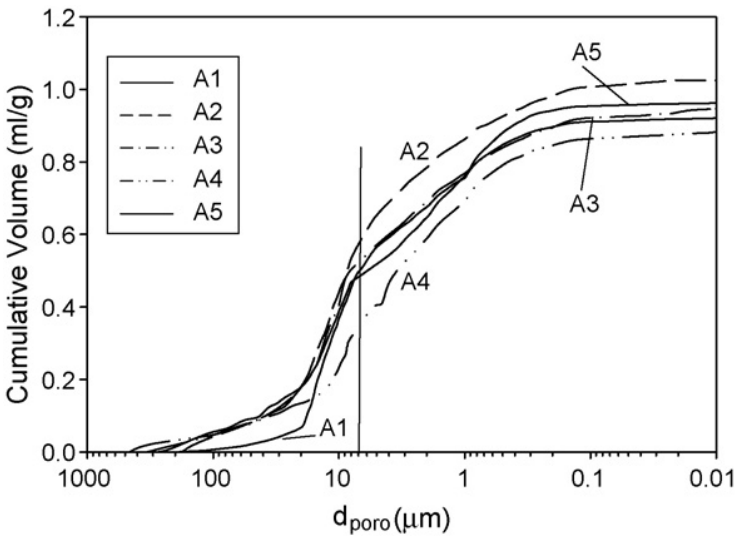

Fig. 4. Cumulative volume of $\mathrm{Hg}$ used in mercury porosimetry experiments.

considered as hazardous due to its toxic characteristics, mainly related with the heavy metals concentration. In what regards the total elemental concentration (TC), several studies refer data, which were often obtained by destructive techniques, such as acid digestions followed by atomic absorption spectrometry techniques $[7,40,42,50,51,59,60]$. However, non-destructive techniques may be also used such as X-ray fluorescence (XRF), and in our study a sample (A2) is analysed through this method. XRF allowed the identification of about 20 different elements, and the major peaks were related with $\mathrm{Ca}, \mathrm{Cl}, \mathrm{K}$ and $\mathrm{S}$, and the minor with $\mathrm{Fe}, \mathrm{Cr}, \mathrm{Ti}, \mathrm{P}, \mathrm{Si}, \mathrm{Al}, \mathrm{Mg}, \mathrm{Na}, \mathrm{Cu}, \mathrm{Zn}, \mathrm{Ba}, \mathrm{Sn}, \mathrm{Sb}$, $\mathrm{Sr}, \mathrm{Br}$ and $\mathrm{Pb}$. As will be discussed below, additional elements are also present in APC residues, such as $\mathrm{Cd}, \mathrm{Ni}$ and $\mathrm{Hg}$, which were identified by destructive methods. These elements could not be identified by XRF because they are in amounts below the detection limits.

The values indicated in Table 4 corresponding to samples $\mathrm{A} 1-\mathrm{A} 5$ are mean values from at least three measurements in each case. For determining the total amount of $\mathrm{Pb}, \mathrm{Cd}, \mathrm{Zn}, \mathrm{Cr}, \mathrm{Ni}, \mathrm{Cu}$, $\mathrm{K}, \mathrm{Na}, \mathrm{Ca}, \mathrm{Fe}, \mathrm{Al}, \mathrm{Si}$, three different digestion protocols were tested (TC1, TC2 and TC3). The amounts indicated in Table 4 for $\mathrm{Pb}, \mathrm{Zn}, \mathrm{Cr}, \mathrm{Ni}, \mathrm{Cu}, \mathrm{Ca}, \mathrm{Fe}$ and $\mathrm{Al}$ were considered the ones obtained through digestion with aqua regia (TC2); the amounts of $\mathrm{K}$ and $\mathrm{Na}$ were determined through nitric acid (TC1); and the quantities concerning $\mathrm{Cd}$ and $\mathrm{Si}$ were the ones found with the acid protocol that involves nitric acid and fluoridric acid (TC3). The chloride concentrations were obtained through the total availability tests considering that the total amount leached out. Fig. 5(a)-(f) shows a comparison of the total elemental amount for various elements $(\mathrm{Pb}, \mathrm{Cd}, \mathrm{Zn}, \mathrm{Cr}, \mathrm{Ni}$ and $\mathrm{Cu})$ obtained through those acid digestions (TC1, TC2, TC3), for samples A1-A5. By performing one-way analysis of variance (ANOVA), and taking a significance value of 0.05 , some conclusions can be indicated:

- $\mathrm{Pb}$ : The acid digestions $\mathrm{TC} 1$ and $\mathrm{TC} 2$ are statistically similar, but different from TC3. When an acid mixture of HF and $\mathrm{HNO}_{3}$ (TC3) is used, a lower amount of $\mathrm{Pb}$ is released, being then considered that the TC2 protocol (aqua regia) gives better results for determining the $\mathrm{Pb}$ amount. The samples $\mathrm{A} 1-\mathrm{A} 5$ are statistically different concerning $\mathrm{Pb}$ content. 
Table 4

Total elemental contents for APC residues (samples A1-A5)

\begin{tabular}{|c|c|c|c|c|c|c|c|}
\hline & Digestion & A1 & $\mathrm{A} 2$ & A3 & A4 & A5 & Mean \\
\hline $\mathrm{Pb}(\mathrm{mg} / \mathrm{kg})$ & $\mathrm{TC} 2$ & 2338 & 1924 & 1853 & 2408 & 2194 & 2143 \\
\hline $\mathrm{Cd}(\mathrm{mg} / \mathrm{kg})$ & TC3 & 65 & 57 & 74 & 87 & 75 & 72 \\
\hline $\mathrm{Zn}(\mathrm{mg} / \mathrm{kg})$ & $\mathrm{TC} 2$ & 5826 & 4308 & 5642 & 6367 & 4939 & 5416 \\
\hline $\mathrm{Ni}(\mathrm{mg} / \mathrm{kg})$ & $\mathrm{TC} 2$ & 132 & 121 & 113 & 87 & 60 & 103 \\
\hline $\mathrm{Cu}(\mathrm{mg} / \mathrm{kg})$ & TC2 & 568 & 456 & 647 & 600 & 504 & 555 \\
\hline $\mathrm{K}(\mathrm{g} / \mathrm{kg})$ & $\mathrm{TC} 1$ & 28.3 & 28.5 & 24.2 & 24.9 & 30.2 & 27.2 \\
\hline $\mathrm{Fe}(\mathrm{g} / \mathrm{kg})$ & $\mathrm{TC} 2$ & 11.4 & 16.1 & 13.2 & 9.94 & 9.62 & 12.1 \\
\hline $\mathrm{Al}(\mathrm{g} / \mathrm{kg})$ & $\mathrm{TC} 2$ & 40.0 & 39.1 & 29.9 & 36.5 & 35.1 & 36.1 \\
\hline $\mathrm{Si}(\mathrm{g} / \mathrm{kg})$ & TC3 & 45.4 & 59.9 & 65.5 & 83.1 & 68.5 & 64.5 \\
\hline $\mathrm{Cl}^{-}(\mathrm{g} / \mathrm{kg})$ & & 118.9 & 106.4 & 101.1 & 131.9 & 138.3 & 119.3 \\
\hline $\mathrm{Hg}(\mathrm{mg} / \mathrm{kg})$ & & 16.31 & 9.22 & 10.14 & 15.40 & nd & 12.8 \\
\hline $\mathrm{C}(\%)$ & & 2.89 & 6.55 & 6.44 & 5.63 & 2.84 & 4.87 \\
\hline
\end{tabular}

$\mathrm{TC} 1: \mathrm{HNO}_{3} ; \mathrm{TC} 2$ : aqua regia; $\mathrm{TC} 3: \mathrm{HF}+\mathrm{HNO}_{3}$; nd: not determined; $\mathrm{LD}$ : limit of detection.

- Cd: Although the results do not seem different, the ANOVA analysis show that the protocols TC1-TC3 are statistically different as well as the samples A1-A5. The quantification of $\mathrm{Cd}$ may be obtained through TC2 or TC3 protocol.
- Zn: The amounts of zinc for samples A1-A5 are different, but any of the acid mixtures (TC1-TC3) gives similar results.

- Cr: The quantities of chromium seem to be more dependent on the type of the acid digestion than on the sample. The TC3 protocol leads to lower quantities than the TC1 and TC2. The
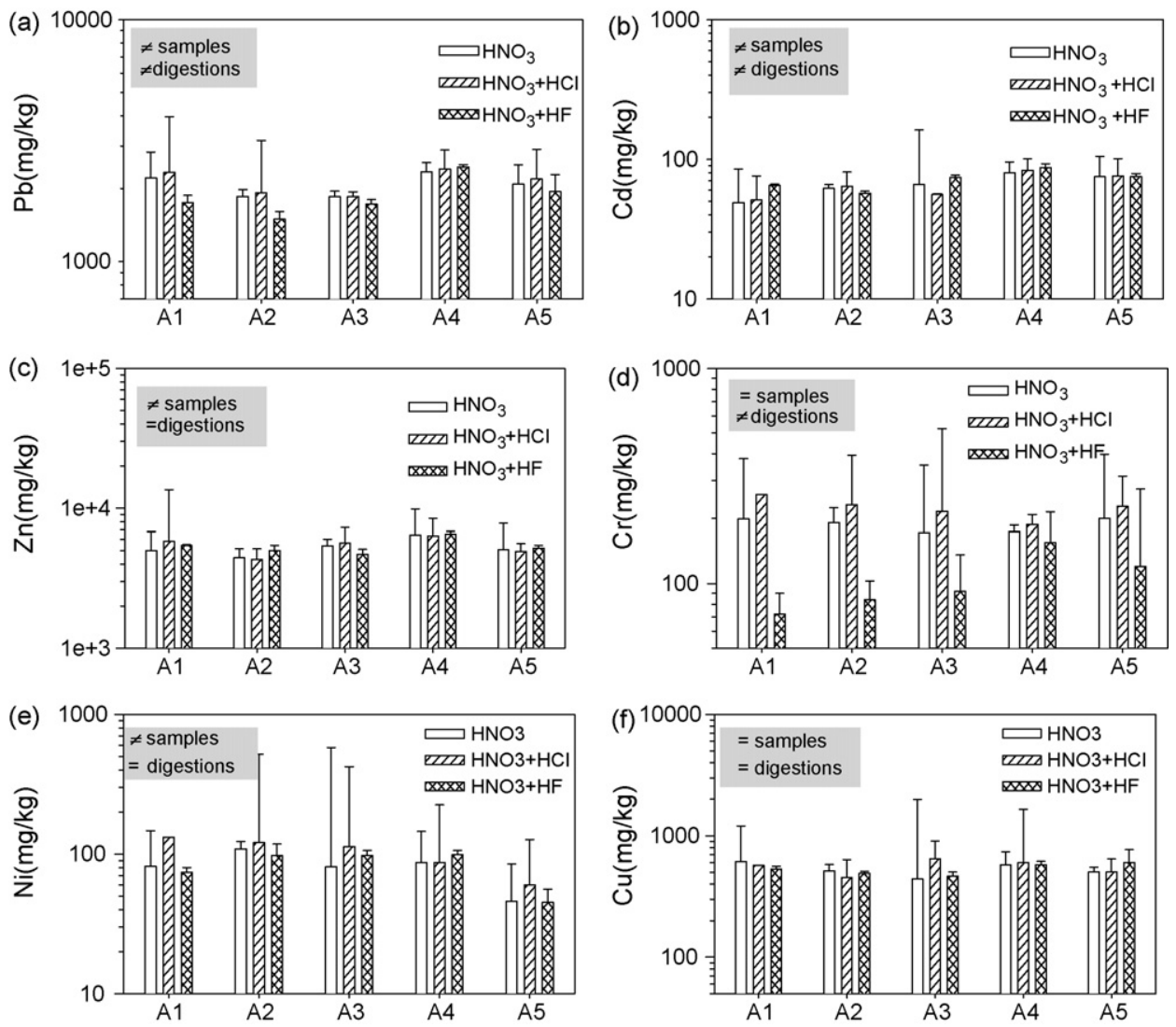

Fig. 5. Comparison of the total elemental content through acid digestions with $\mathrm{HNO}_{3}, \mathrm{HCl}+\mathrm{HNO}_{3}$ and $\mathrm{HNO}_{3}+\mathrm{HF}$, for samples $\mathrm{A}$ 1- $\mathrm{A}$ 5: (a) $\mathrm{Pb}$; (b) $\mathrm{Cd}$; (c) $\mathrm{Zn}$; (d) $\mathrm{Cr}$; (e) $\mathrm{Ni}$; (f) $\mathrm{Cu}$. 
final results were established through the aqua regia determinations (TC2). The samples (A1-A5) may be considered statistically similar in respect to this element.

- Ni: Although the differences are low, the samples are statistically different and the digestion protocols are identical concerning nickel content.

- $\mathrm{Cu}$ : In this case, samples and digestions protocols may be considered statistically identical.

- $\mathrm{K}$ and $\mathrm{Na}$ : In order to determine the total elemental quantities of these elements, it was considered that the digestions with only nitric acid (TC1) gave truthfully results.

- Ca: Both TC1 and TC2 provided similar amounts, and when TC3 was used the quantity of calcium was lower. This result may be related with the possibility of being formed insoluble calcium fluorides (though boric acid was added after digestion).

- Fe and Al: The ANOVA established that samples (A1-A5) and digestion protocols (TC1-TC3) are different. However, TC1 and TC2 lead to similar results.

- Si: For silicium the protocols TC1 and TC2 were not adequate, and in this case it was absolutely necessary to use HF acid.

From these results one may conclude that the use of HF is not necessary for determining the elemental quantities concerning $\mathrm{Pb}, \mathrm{Cd}, \mathrm{Zn}, \mathrm{Cr}, \mathrm{Ni}, \mathrm{Cu}, \mathrm{K}, \mathrm{Na}, \mathrm{Ca}, \mathrm{Fe}$ and $\mathrm{Al}$, whereas it was essential for obtaining Si content.

The total quantity of carbon may be different among samples, Table 4, and for samples A1-A5 values from $2.89 \%$ to $6.55 \%$ were obtained. A low concentration of hydrogen and sulphur was found while nitrogen was not detected through elemental analysis technique. Concerning oxygen only the sample A5 was analysed and a significant amount was determined (19.24\%). The quantity of oxygen obtained in our study is in accordance with the literature [51]. It is important to note that the elemental analysis does not give indication about the chemical species in which the carbon is involved. Even if it is clear from the literature that one of the main concerns is related to dioxins and furans [69-74], other studies refer that more than 600 organic micropollutants were identified [80]. In our study, the total carbon content for sample A5 is $2.84 \%$ (Table 4 ) and according to a preliminary analysis, only $35.6 \%$ of the total carbon content is organic and $64.4 \%$ may be in inorganic forms (carbonates). These results were obtained by heating sub-samples with $\mathrm{HCl} 1 \mathrm{M}$, in order to eliminate the carbonate compounds. Other important result is the low percentage of the organic carbon that may be dissolved (DOC) in water. In fact, the results showed that only $0.4 \%$ of the carbon in the solid phase may be dissolved, and through a TOC analysis (5000A-Shimadzu) it was observed that only $56.9 \mathrm{mg} / \mathrm{kg}$ of organic carbon and $53.3 \mathrm{mg} / \mathrm{kg}$ of inorganic carbon were dissolved. For a comprehensive analysis in order to determine the carbon speciation, several analytical techniques may be used in a complementary way to the elemental analysis, such as mass spectroscopy, FTIR, thermogravimetric analysis and GC-MS [80].

Table 5 shows the values obtained for the total availability for $\mathrm{Pb}, \mathrm{Cd}, \mathrm{Zn}, \mathrm{Cr}, \mathrm{Ni}, \mathrm{Cu}, \mathrm{K}, \mathrm{Na}, \mathrm{Fe}, \mathrm{Al}, \mathrm{Si}$ and $\mathrm{Cl}^{-}$concerning samples A1-A5, as well as the ratio TA/TC. It should be noted that this test was designed to determine the quantities that leach out from the solids when exposed to extreme conditions such as long time periods, disintegration of material, full oxidation and after loss of acid neutralisation capacity in an aerobic ambient. This method has been often used to APC residues [51,57,61]. The percentages indicated in Table 5 allow the comparison of amounts that may be released from the waste under aggressive conditions (TA) and the quantity that is really present (TC) in the solid. Considering the different elements, the behaviour can be diverse, and Fig. 6 illustrates clearly the amount in percentage, that may be released into the environment under aggressive conditions. Therefore, according to NEN 7341, our results showed that only $6 \%$ of $\mathrm{Pb}$ will be released into the environment; about $90 \%$ of $\mathrm{Cd}$ can be released; $\mathrm{Zn}$ and $\mathrm{Cu}$ may be extracted around $50 \%$ and $40 \%$, respectively; for $\mathrm{Cr}$ and $\mathrm{Ni}$ the driving force for leaching is less than $20 \%$; $\mathrm{K}$ and $\mathrm{Na}$ are associated with highly soluble salts, and therefore close to $100 \%$ may be released; Fe, $\mathrm{Al}$ and $\mathrm{Si}$ are usually associated to geologically stable phases, and leach out in very low levels. No results are indicated for calcium, because for this element the determinations were not reliable. It is important to note that the results concerning $\mathrm{Pb}$ are underestimated by this test NEN 7341, since the predicted amount of about $6 \%$ is exceeded when the waste is in contact with water. This is a well-understood behaviour, related with the amphoteric characteristics of the element. Indeed, when the waste contacts with water the $\mathrm{pH}$ is higher than 12 and in these conditions higher concentrations of $\mathrm{Pb}$ are released, as it will be shown below.

Based on the quantities of nitric acid used for $\mathrm{pH}$ control at 7 and 4 during the availability tests (NEN 7341), the acid neutralization capacity (ANC) was estimated for samples A1-A5, which is a measure of the capacity of the waste to neutralize acids. Thus, by controlling $\mathrm{pH}$ in 7 for $3 \mathrm{~h}$, in average 4.2 to 6.5 mequiv./g were required and taking as reference $\mathrm{pH}$ equal to 4 , the $\mathrm{ANC}$ is in the range of 7.6 to 9.3 mequiv./g. The variation among samples is mainly related with the quantity of lime slurry used during the gaseous clean up operations.

Some leaching tests were used for evaluating the compliance with regulatory thresholds, namely DIN 38414-S4, TCLP, AFNOR X 31-210. In this study DIN 38414-S4 was the most used, and Table 6 shows the main results. The legal limits included in this table correspond to the regulatory Portuguese legislation (Decreto-Lei $\mathrm{n}^{\circ}$ 152/2002) thresholds for considering hazardous waste, which is in agreement with the Directive 1999/31/CE. For calculating the mean values as well as the con-

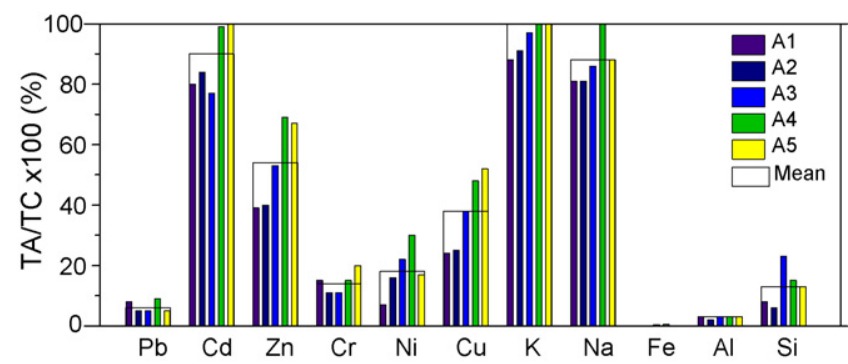

Fig. 6. Ratio TA/TC (\%) for $\mathrm{Pb}, \mathrm{Cd}, \mathrm{Zn}, \mathrm{Cr}, \mathrm{Ni}, \mathrm{Cu}, \mathrm{K}, \mathrm{Na}, \mathrm{Fe}, \mathrm{Al}$ and $\mathrm{Si}$, for samples A1-A5 and mean value. 
Table 5

Total availability (TA) and TA/TC ratio for samples A1-A5

\begin{tabular}{|c|c|c|c|c|c|c|c|}
\hline \multirow[t]{2}{*}{ Element } & & \multicolumn{6}{|l|}{ Samples } \\
\hline & & A1 & A2 & A3 & A4 & A5 & Mean \\
\hline \multirow{2}{*}{$\mathrm{Pb}$} & TA (mg/kg) & 189 & 104 & 94 & 216 & 108 & 142 \\
\hline & TA/TC2 (\%) & 8 & 5 & 5 & 9 & 5 & 6 \\
\hline \multirow{2}{*}{$\mathrm{Cd}$} & TA (mg/kg) & 52 & 48 & 57 & 86 & 83 & 65 \\
\hline & TA/TC3 (\%) & 80 & 84 & 77 & 99 & $100^{\mathrm{a}}$ & 90 \\
\hline \multirow{2}{*}{$\mathrm{Zn}$} & $\mathrm{TA}(\mathrm{mg} / \mathrm{kg})$ & 2279 & 1700 & 3013 & 4360 & 3328 & 2936 \\
\hline & TA/TC2 (\%) & 39 & 40 & 53 & 69 & 67 & 54 \\
\hline \multirow{2}{*}{$\mathrm{Cr}$} & TA (mg/kg) & 40 & 25 & 24 & 28 & 45 & 32 \\
\hline & TA/TC2 (\%) & 15 & 11 & 11 & 15 & 20 & 14 \\
\hline \multirow{2}{*}{$\mathrm{Ni}$} & TA (mg/kg) & 9 & 19 & 25 & 26 & 10 & 18 \\
\hline & TA/TC2 (\%) & 7 & 16 & 22 & 30 & 17 & 18 \\
\hline \multirow{2}{*}{$\mathrm{Cu}$} & TA (mg/kg) & 136 & 115 & 249 & 288 & 262 & 210 \\
\hline & TA/TC2 (\%) & 24 & 25 & 38 & 48 & 52 & 38 \\
\hline \multirow{2}{*}{$\mathrm{K}$} & $\mathrm{TA}(\mathrm{g} / \mathrm{kg})$ & 24.9 & 25.9 & 23.6 & 28.6 & 32.5 & 27.1 \\
\hline & TA/TC1 $(\%)$ & 88 & 91 & 97 & $100^{\mathrm{a}}$ & $100^{\mathrm{a}}$ & 100 \\
\hline \multirow{2}{*}{$\mathrm{Na}$} & $\mathrm{TA}(\mathrm{g} / \mathrm{kg})$ & 23.8 & 23.5 & 24.2 & 28.4 & 29.3 & 25.8 \\
\hline & TA/TC1 (\%) & 81 & 81 & 86 & $100^{\mathrm{a}}$ & 88 & 88 \\
\hline \multirow{2}{*}{$\mathrm{Fe}$} & TA (mg/kg) & 20 & 35 & 59 & 46 & 17 & 35 \\
\hline & TA/TC2 (\%) & 0.2 & 0.2 & 0.4 & 0.5 & 0.2 & 0.3 \\
\hline \multirow{2}{*}{$\mathrm{Al}$} & TA (mg/kg) & 1176 & 664 & 1022 & 1190 & 1152 & 1041 \\
\hline & TA/TC2 (\%) & 3 & 2 & 3 & 3 & 3 & 3 \\
\hline \multirow[b]{2}{*}{$\mathrm{Si}$} & $\mathrm{TA}(\mathrm{g} / \mathrm{kg})$ & 3.4 & 3.5 & 14.8 & 12.2 & 8.9 & 8.6 \\
\hline & TA/TC3 $(\%)$ & 8 & 6 & 23 & 15 & 13 & 13 \\
\hline \multirow{2}{*}{$\mathrm{Cl}^{-}$} & $\mathrm{TA}(\mathrm{g} / \mathrm{kg})$ & 118.9 & 106.4 & 101.1 & 131.9 & 138.3 & 119.3 \\
\hline & TA/TC $(\%)$ & b & b & b & b & b & $\approx 100$ \\
\hline
\end{tabular}

nd: not determined.

a TA/TC slightly $>100 \%$ and therefore admitted as $100 \%$.

b TC not determined.

Table 6

Results obtained according DIN 38414-S4 for samples A1-A5

\begin{tabular}{|c|c|c|c|c|c|c|c|}
\hline & \multirow[t]{2}{*}{ Legal limits } & \multicolumn{6}{|l|}{ Samples } \\
\hline & & $\mathrm{A} 1(n=8)^{\mathrm{a}}$ & A2 $(n=10)^{\mathrm{a}}$ & $\mathrm{A} 3(n=5)^{\mathrm{a}}$ & $\mathrm{A} 4(n=6)^{\mathrm{a}}$ & $\mathrm{A} 5(n=6)^{\mathrm{a}}$ & Mean \\
\hline $\mathrm{pH}$ & $4-13$ & $12.4 \pm 0.2$ & $12.5 \pm 0.2$ & $12.9 \pm 0.1$ & $12.8 \pm 0.03$ & $12.5 \pm 0.02$ & $12.6 \pm 0.3$ \\
\hline Conductivity $(\mathrm{mS} / \mathrm{cm})$ & 100 & $40.8 \pm 1.1$ & $37.5 \pm 0.6$ & $38.0 \pm 0.5$ & $41.3 \pm 0.8$ & $39.5 \pm 0.5$ & $39.4 \pm 2.1$ \\
\hline TDS $(\mathrm{g} / \mathrm{L})$ & nd & $24.6(*)$ & $22.2 \pm 0.4$ & $22.2 \pm 0.9$ & $25.6 \pm 0.7$ & $24.5 \pm 0.5$ & $23.8 \pm 2.8$ \\
\hline DOC (mg/kg) & 2000 & $\mathrm{nq}$ & $\mathrm{nq}$ & $\mathrm{nq}$ & $\mathrm{nq}$ & $56.9 \pm 1.9$ & 56.9 \\
\hline $\mathrm{Pb}(\mathrm{mg} / \mathrm{kg})$ & 20 & $483 \pm 59$ & $324 \pm 48$ & $460 \pm 45$ & $444 \pm 9$ & $462 \pm 72$ & $435 \pm 79$ \\
\hline $\mathrm{Cd}(\mathrm{mg} / \mathrm{kg})$ & 5 & $0.20(*)$ & $0.15 \pm 0.06$ & $0.18 \pm 0.08$ & $0.20 \pm 0.07$ & $<\mathrm{LD}$ & $0.18 \pm 0.04$ \\
\hline $\mathrm{Zn}(\mathrm{mg} / \mathrm{kg})$ & 100 & $44.0 \pm 6.0$ & $50.5 \pm 3.6$ & $63.0 \pm 4.7$ & $45.9 \pm 5.3$ & $43.4 \pm 3.1$ & $49.4 \pm 10$ \\
\hline Cr total $(\mathrm{mg} / \mathrm{kg})$ & 50 & $6.54 \pm 0.74$ & $5.97 \pm 1.28$ & $6.21 \pm 1.00$ & $7.26 \pm 0.77$ & $5.92 \pm 0.71$ & $6.4 \pm 0.7$ \\
\hline $\mathrm{Ni}(\mathrm{mg} / \mathrm{kg})$ & 20 & $2.21 \pm 0.61$ & $2.54 \pm 0.31$ & $1.74 \pm 0.37$ & $2.01 \pm 0.30$ & $0.10 \pm 0.09$ & $1.7 \pm 1.2$ \\
\hline $\mathrm{Cu}(\mathrm{mg} / \mathrm{kg})$ & 100 & $0.86 \pm 0.32$ & $1.38 \pm 0.45$ & $1.97 \pm 0.36$ & $1.24 \pm 0.11$ & $0.17 \pm 0.07$ & $1.1 \pm 0.8$ \\
\hline $\mathrm{Hg}(\mathrm{mg} / \mathrm{kg})$ & 1 & nq & $\mathrm{nq}$ & nq & nq & $0.189 \pm 0.019$ & 0.189 \\
\hline $\mathrm{K}(\mathrm{g} / \mathrm{kg})$ & nd & $27.0 \pm 1.4$ & $26.6 \pm 1.0$ & $23.1 \pm 0.5$ & $22.7 \pm 0.5$ & $31.8 \pm 1.3$ & $26.2 \pm 4.6$ \\
\hline $\mathrm{Na}(\mathrm{g} / \mathrm{kg})$ & nd & $22.2 \pm 1.4$ & $22.4 \pm 0.7$ & $20.6 \pm 0.3$ & $24.8 \pm 0.4$ & $25.6 \pm 0.3$ & $23.1 \pm 2.5$ \\
\hline $\mathrm{Ca}(\mathrm{g} / \mathrm{kg})$ & nd & $33.8(*)$ & $40.9 \pm 11$ & $51.3 \pm 5.7$ & $94.5 \pm 7.6$ & $96.7 \pm 10$ & $63.4 \pm 37$ \\
\hline $\mathrm{Cl}^{-}(\mathrm{g} / \mathrm{kg})$ & 100 & $114.5(*)$ & $98.4 \pm 2.1$ & $96.3 \pm 4.4$ & $110.8 \pm 2.4$ & $125.1 \pm 1.8$ & $109 \pm 1.5$ \\
\hline $\mathrm{SO}_{4}{ }^{2-}(\mathrm{g} / \mathrm{kg})$ & 50 & $19.2(*)$ & $20.49 \pm 2.6$ & $\mathrm{nq}$ & $\mathrm{nq}$ & $15.3 \pm 4.1$ & $18.3 \pm 6.8$ \\
\hline
\end{tabular}

TDS: total dissolved solids; nd: not defined; nq: not quantified; LD: limit of detection; $(*)$ : only one measurement was performed, and therefore no confidence interval was calculated.

${ }^{\mathrm{a}}$ Values within parenthesis indicate number of sub-samples. 

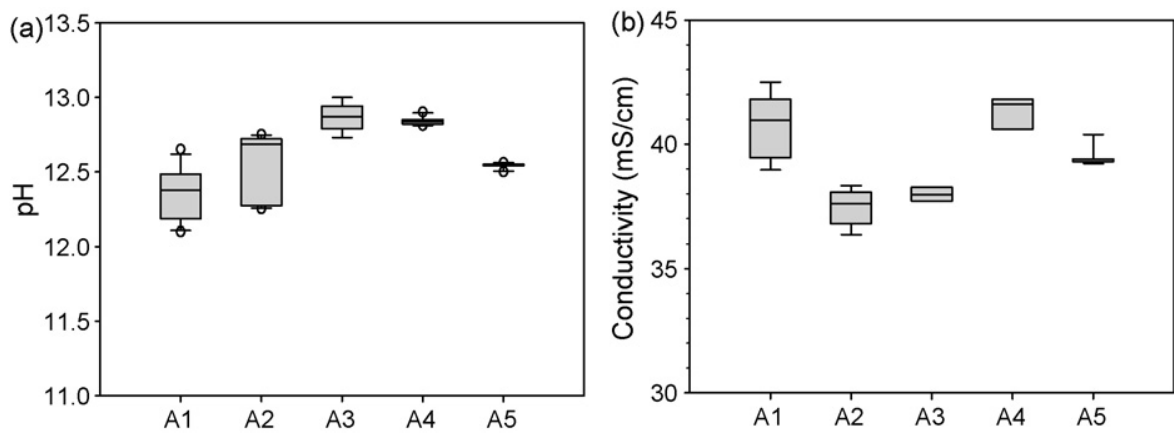

Fig. 7. (a) $\mathrm{pH}$ and (b) conductivity in the DIN 38414 eluates for samples A1-A5.

fidence internals (95\%), the outliers were excluded. The results obtained for samples A1-A5 regarding to $\mathrm{pH}$ and conductivity are depicted in a box-and-whisker plot, Fig. 7, where the horizontal line inside the boxes correspond to the median value. From these results it can be concluded that $\mathrm{pH}$ is always highly basic $(12.2<\mathrm{pH}<13.0)$, and the conductivity is in the range $36-43 \mathrm{mS} / \mathrm{cm}$. Through an ANOVA analysis with a significance value $(p)$ of 0.05 , the samples A1-A5 are statistically different in order to $\mathrm{pH}$ as well as concerning conductivity. The values of conductivity are related to total dissolved solids (TDS), which are in the range of $21.6-26.8 \mathrm{~g} / \mathrm{L}$ (considering all measurements), and the mean values for the different samples are $22.2-25.6 \mathrm{~g} / \mathrm{L}$ (Table 6). The high amount of TDS is mainly related to soluble salts such as $\mathrm{NaCl}, \mathrm{KCl}$ and some calcium salts. By comparing the mean values (considering the confidence intervals) with the regulatory limits for $\mathrm{pH}$ it should be concluded that this parameter could occasionally exceed the upper limit of 13. Concerning the conductivity and taking into account that this parameter depends on the $\mathrm{L} / \mathrm{S}$ ratio $(10 \mathrm{~mL} / \mathrm{g}$ in this case) the legal limit of $100 \mathrm{mS} / \mathrm{cm}$ should not be surpassed in any situation. Though the dissolved organic carbon (DOC) was only measured for sample A5, it is possible to conclude that this parameter will hardly exceeds the limit of $2000 \mathrm{mg} / \mathrm{kg}$, since the obtained value was $56.9 \mathrm{mg} / \mathrm{kg}$.

Regarding toxic heavy metals $(\mathrm{Pb}, \mathrm{Cd}, \mathrm{Zn}, \mathrm{Cr}, \mathrm{Ni}, \mathrm{Cu}$ and $\mathrm{Hg}$ ), from Table 6 or more clearly through Fig. 8, one may conclude that the APC residues surely represent environmental concern, mainly due to the high $\mathrm{Pb}$ amount that may leach out, if the residue contacts with 10 times more leachant $(\mathrm{L} / \mathrm{S}=10)$. In fact, the regulatory limit is exceeded more than 20 times. It is worthy to underline that about $20 \%$ the total elementary content (TC) of $\mathrm{Pb}$ was released, while only $6 \%$ was predicted before with the total availability parameter, determined by NEN 7341. For this reason one may refer that NEN 7341 fails for $\mathrm{Pb}$. Fig. 8 shows that $\mathrm{Cd}, \mathrm{Zn}, \mathrm{Cr}$ total, $\mathrm{Ni}$ and $\mathrm{Cu}$ never exceeded the regulatory threshold. The concentrations of $\mathrm{Hg}$ were determined in few cases due to the difficulties observed in the analytical work. In fact, the used technique (hydride generation accomplished with flame atomic absorption spectrophotometry) showed interference problems mainly as a result of the high chloride concentration. However, from Table 6 one may conclude that seldom the legal limit $(1 \mathrm{mg} / \mathrm{kg})$ will be exceeded. Contrarily, the amounts of $\mathrm{K}, \mathrm{Na}$ and $\mathrm{Ca}$ in the eluates are very high, but for these elements no legal limit is established, and their effects are mainly taken into account in the conductivity (or TDS). For chlorides the legal limit is $100 \mathrm{~g} / \mathrm{kg}$, and that value is exceeded for all samples, if the confidence interval is taken into account. Therefore, chlorides represent a critical parameter for APC residues, which should always be considered during characterization studies. The sulphates concentrations were determined through ionic chromatography, and due to the high quantity of $\mathrm{Cl}^{-}$, the peaks for $\mathrm{SO}_{4}{ }^{2-}$ were difficult to detect for most cases. However, by comparing the results obtained with the limit $(50 \mathrm{mg} / \mathrm{kg})$ it is possible to conclude that this anion does not involve regulatory problems for this residue. The main conclusion from this study is the fact that the five different samples of the APC residues analysed should be considered hazardous, and therefore should be treated before landfilled. From ANOVA analysis, the samples A1-A5 can only be considered similar in respect to $\mathrm{Cd}$ and $\mathrm{Cr}$, since the significance parameter $(p)$ is higher than 0.05 . In respect to $\mathrm{Pb}, \mathrm{Zn}, \mathrm{Ni}, \mathrm{Cu}, \mathrm{K}, \mathrm{Na}, \mathrm{Ca}, \mathrm{Cl}^{-}$ and $\mathrm{SO}_{4}{ }^{2-}$ the ANOVA indicates values $<0.05$, and therefore the samples should be considered different.

The analysis of the ionic balance for the major species in the eluates, Eq. (3.1), allows to ensure that the major species were quantified:

$\sum z_{\mathrm{i}} C_{\mathrm{i}, \text { pos }}=\sum z_{\mathrm{i}} C_{\mathrm{i}, \text { neg }}$

where $z_{\mathrm{i}}$ is the ion charge (positive or negative), $C_{\mathrm{i}, \text { pos }}$ the concentration of positive ions and $C_{\mathrm{i}, \text { neg }}$ is the concentration of negative ions $(\mathrm{mmol} / \mathrm{L})$. The cations considered in that balance were $\mathrm{Ca}^{2+}, \mathrm{Na}^{+}$and $\mathrm{K}^{+}$, and the anions were $\mathrm{Cl}^{-}, \mathrm{SO}_{4}{ }^{2-}$ and $\mathrm{OH}^{-}$. The minimum difference of $2 \%$ was observed for sample A2, while the maximum difference was about $10 \%$.

The ionic strength, $I$, is also an important parameter for the eluates, and is defined by Eq. (3.2),

$I=\frac{1}{2} \sum c_{\mathrm{i}} z_{\mathrm{i}}^{2}$

where $c_{\mathrm{i}}$ is the concentration of the ion $\mathrm{i}(\mathrm{mol} / \mathrm{L})$ and $z_{\mathrm{i}}$ is the charge of ion i. By taking the mean values indicated in the right column of Table 6 , the calculated ionic strength of these eluates is close to $0.6 \mathrm{M}$. It should be noted that when $\mathrm{L} / \mathrm{S}$ decreases the ionic strength increases. According to this value the models of Debuy-Huckel or Davies may not be used for estimating the 

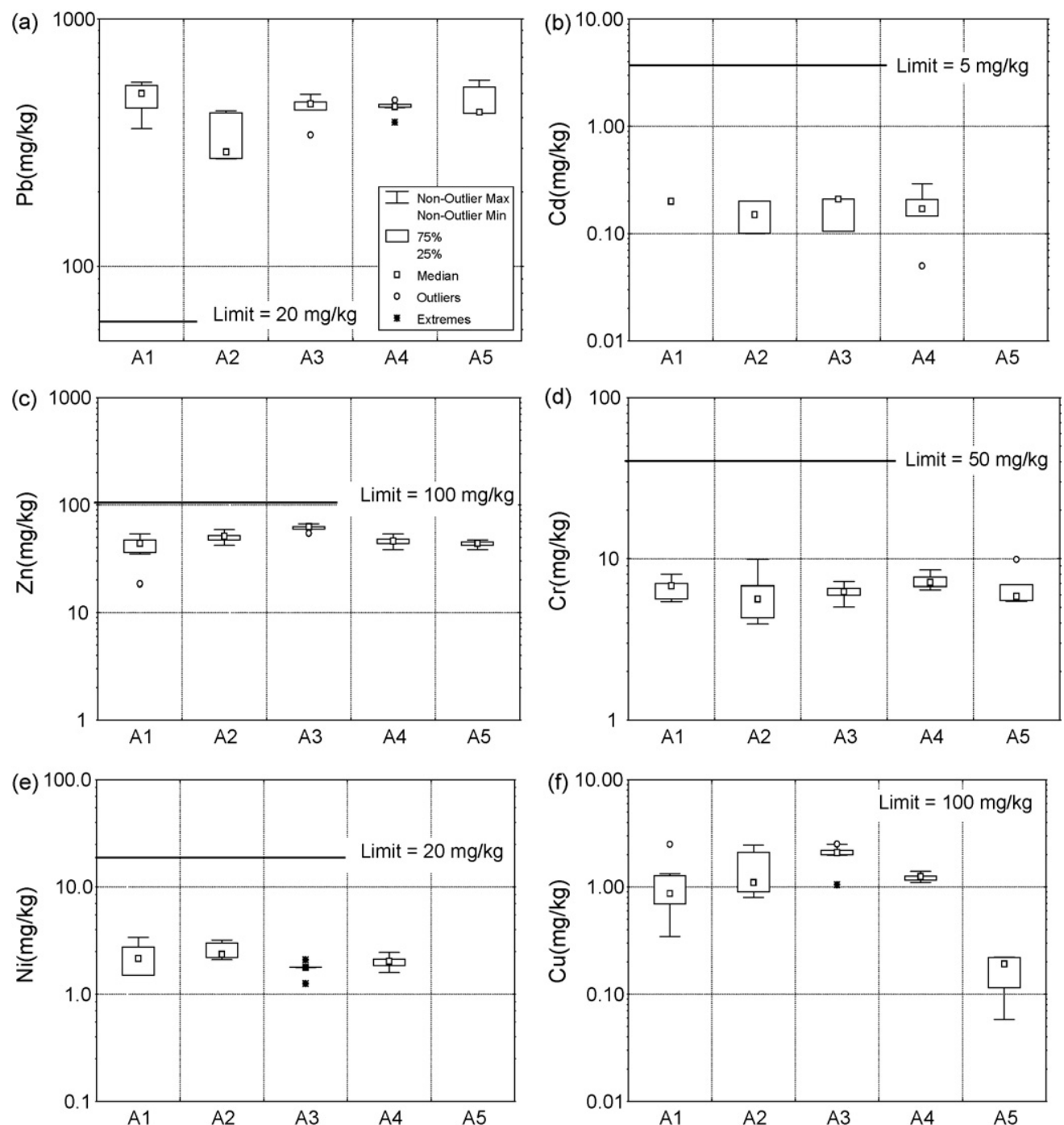

Fig. 8. Released amounts for samples A1-A5 in the DIN 38414 eluates: (a) Pb; (b) Cd; (c) Zn; (d) Cr; (e) Ni; (f) $\mathrm{Cu}$.

activity coefficients, since they are limited to the cases where ionic strength is less than 0.005 or $0.5 \mathrm{M}$, respectively [1].

Other important result of our work is related with the uncertainty associated to the measurements of concentration in leachates from DIN 38414. According to the methodology indicated in the literature [79], when a measurement is for example $638 \mathrm{mg} / \mathrm{kg}$, the uncertainty associated to that value is $\pm 24 \mathrm{mg} / \mathrm{kg}$ (for a coverage factor $k=2$ ). The uncertainty calculations showed that the calibration procedures during FAAS analysis and the dilution of samples are the most important phases.
In order to compare different compliance tests, DIN 38414, AFNOR X 31-210 and TCLP were used for sample A1, and the obtained results for $n$ sub-samples were resumed in Table 7, for $\mathrm{Pb}, \mathrm{Zn}, \mathrm{Cr}, \mathrm{Ni}$ and $\mathrm{Cu}$, where the respective limits for each test are also referred. All the leaching tests give similar results for $\mathrm{Pb}$, which means that the residue is hazardous accordingly all those regulatory tests. Although for TCLP method a more aggressive leachant solution is used, the released amount of $\mathrm{Pb}$ is lower than for the cases where water is used (DIN 38414 and AFNOR X 31-210). This is in agreement with the amphoteric behaviour of $\mathrm{Pb}$. For the other heavy metals $(\mathrm{Zn}, \mathrm{Cr}, \mathrm{Ni}$ and $\mathrm{Cu}$ )

Table 7

Released quantities (mg/kg) for sample A1, according to standard methods (DIN 38414, X 31-210 and TCLP)

\begin{tabular}{|c|c|c|c|c|c|c|c|c|c|c|c|}
\hline & \multirow[t]{2}{*}{$n$} & \multicolumn{2}{|l|}{$\mathrm{Pb}$} & \multicolumn{2}{|l|}{$\mathrm{Zn}$} & \multicolumn{2}{|l|}{$\mathrm{Cr}$} & \multicolumn{2}{|l|}{$\mathrm{Ni}$} & \multicolumn{2}{|l|}{$\mathrm{Cu}$} \\
\hline & & Mean & Limit & Mean & Limit & Mean & Limit & Mean & Limit & Mean & Limit \\
\hline DIN 38414 & 8 & 483 & 20 & 44.0 & 100 & 6.5 & 50 & 2.2 & 20 & 0.9 & 100 \\
\hline TCLP & 5 & 209 & 100 & 32.4 & nd & 10.0 & nd & 5.3 & nd & 2.5 & nd \\
\hline
\end{tabular}

nd: not defined. 
none limit is exceeded and therefore the same conclusions are obtained through the different standards.

Finally, it is worthy to emphasize that the chemical behaviour of the APC residues is strongly dependent of their mineral composition. The total availability and leaching behaviour are mainly determined by the chemical speciation of the solid material and in less extent from the total content. Indeed, the matrix mineralogy has a relevant effect on the chemical properties of the solid.

\subsection{Mineralogy}

In spite of the complexity of the mineralogical composition of APC residues, some literature indicates a comprehensive analysis, where the main mineralogical phases are identified [12,36,40,42,50,51,59,64-67]. According to Le Forestier and Libourel [40] the complex mineralogy of APC residues is a consequence of several processes that occur during incineration and treatment of flue gases, which may include vaporization, melting, crystallization, vitrification, condensation and precipitation. Furthermore, the APC residues may contain a significant amorphous phases (glass) as referred in various published papers. Quantifications by the Rietveld method for this type of waste showed that amorphous phases may be higher than $30 \%$, namely $33 \%, 47 \%$ and $50 \%$ for three different samples [36]. In another work the solid residues recovered from the treatment of flue gas resulting from the combustion of municipal solid waste were identified as a heterogeneous assemblage of glasses, metals, and other crystals in which polluting elements are distributed [40]. Indeed, this study refers that ESP (electrostatic precipitator) ash samples may contain around $40 \mathrm{wt} . \%$ glass and $60 \mathrm{wt} . \%$ crystallized phases whereas semidry scrubber residues (SDSR) enclose approximately $20 \mathrm{wt} \%$ glass and $80 \mathrm{wt} . \%$ crystallized phases. When bottom and fly ashes were combined, Kirby and Rimstidt indicate that $18 \%$ correspond to minerals, $9 \%$ structural and adsorbed water and $72 \%$ glass [50]. Moreover, studies with municipal solid wastes treated by thermolysis processes also showed a considerable amount of glass material ( $~ 50$ vol. $\%$ ) [82-84].

Taking into account the high number of the elements in APC residues, even before any inspection through X-ray diffraction (XRD), a highly complex mineralogy is expected for these residues. In fact, 20 elements were identified through XRF, plus $\mathrm{Cd}$ and Ni throughout flame atomic absorption spectrophotometry (FAAS) and $\mathrm{Hg}$ by using amalgamation. XRD was used to analyse samples A2 and A5, and Fig. 9 shows the corresponding results. By using the International Centre for Diffraction Data (ICDD) several mineralogical phases were identified: halite $(\mathrm{NaCl})$, sylvite $(\mathrm{KCl})$, calcite $\left(\mathrm{CaCO}_{3}\right)$, anhyidrite $\left(\mathrm{CaSO}_{4}\right)$, quartz $\left(\mathrm{SiO}_{2}\right)$, gehlenite $\left(\mathrm{Ca}_{2} \mathrm{Al}\left(\mathrm{AlSiO}_{7}\right)\right)$, hematite $\left(\mathrm{Fe}_{2} \mathrm{O}_{3}\right)$, portlandite $\left(\mathrm{Ca}(\mathrm{OH})_{2}\right)$ and calcium hydroxychloride $(\mathrm{CaOHCl})$. These phases were identified in both spectra, which are in fact very similar in what regards the crystalinity of both samples $\mathrm{A} 2$ and A5. Moreover, it seems that the phases $\mathrm{KCl}, \mathrm{NaCl}$ and $\mathrm{CaOHCl}$ are present in higher quantities in sample $\mathrm{A} 5$, since the previous results obtained through acid digestion (Table 4) and total availability (Table 5) revealed higher amounts of $\mathrm{Na}$, $\mathrm{K}$ and $\mathrm{Cl}$; this because these species were only detected in those phases. Concerning calcium the analysis is more complex because this element may be found as $\mathrm{CaCO}_{3}, \mathrm{CaSO}_{4}$, $\mathrm{Ca}(\mathrm{OH})_{2}, \mathrm{Ca}_{2} \mathrm{Al}\left(\mathrm{AlSiO}_{7}\right)$ and $\mathrm{CaOHCl}$. Similar mineralogical phases were identified in literature $[20,36,40,42,51,67,81]$ and our results are in particular agreement with the ones presented by Bodéman and Deniard [36], with the exception for gehlenite $\left(\mathrm{Ca}_{2} \mathrm{Al}\left(\mathrm{AlSiO}_{7}\right)\right)$ and hematite $\left(\mathrm{Fe}_{2} \mathrm{O}_{3}\right)$, which were not identified in that work. In our XRD spectra, calcium hydroxychloride was identified instead of $\mathrm{CaCl}_{2}$, which is also in accordance with those researchers [36] that refer that the formation of $\mathrm{CaOHCl}$ is favoured by the solid-gas interactions in dry and semi-dry processes, as it is our case. Moreover, some analysis through fourier

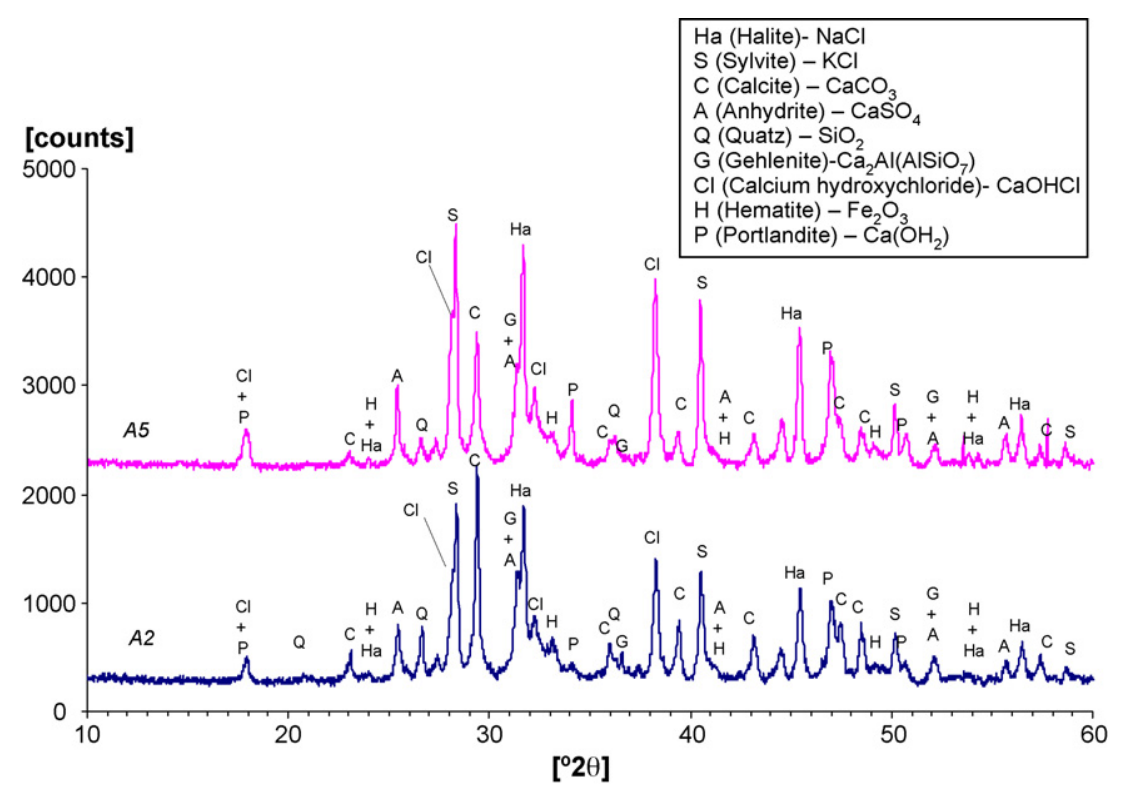

Fig. 9. X-ray diffraction (XRD) results for samples A2 and A5. 


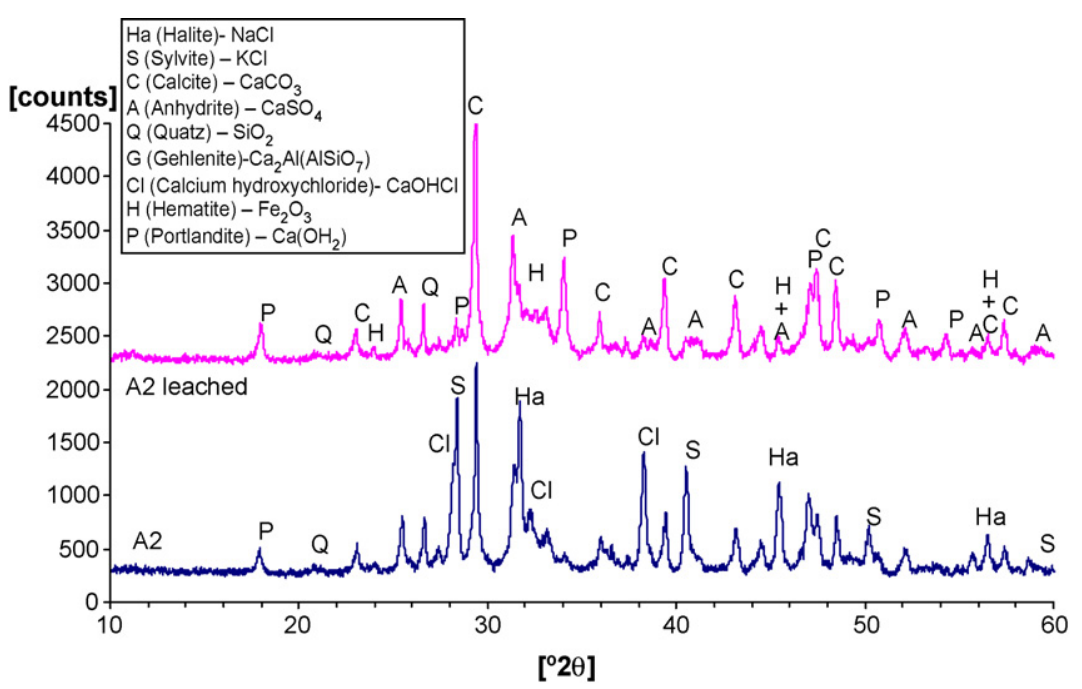

Fig. 10. X-ray diffraction (XRD) results for sample A2 before and after leaching.

transform infrared spectroscopy (FTIR), Nicolet Magna IR System 750 , in $\mathrm{KBr}$ pellets, also showed the patterns of absorption of $\mathrm{CaOHCl}$ at 3572 and $676 \mathrm{~cm}^{-1}$.

As it was referred above, when the APC residues were leached with water (washed), according DIN 38414, more than $20 \%$ is dissolved, and XRD analysis allows the identification of the main solubilized phases. In fact, comparing the curves indicated in Fig. 10, for sample A2, for which a weight loss of $22 \%$ was observed, it is clear that halite $(\mathrm{NaCl})$, sylvite $(\mathrm{KCl})$ and calcium hydroxychloride $(\mathrm{CaOHCl})$, were no longer detected after washing. On the other hand phases such as portlandite, calcite and anhydrite are more pronounced after leaching. Similar observations were referred in other studies $[12,81]$.

Based on our results and in the literature, the most probable phases concerning the major elements $(\mathrm{Ca}, \mathrm{Na}, \mathrm{Cl}, \mathrm{K}, \mathrm{S})$ as well as for the most environmental problematic heavy metals $(\mathrm{Pb}$, $\mathrm{Cd}, \mathrm{Zn}, \mathrm{Cr}, \mathrm{Cu}$ ) are indicated in Table 8 . The phases that probably limited the solubility are also indicated. Besides the phases referred in this Table, other minerals may be present. It should be noted that, with the exception of $\mathrm{Na}, \mathrm{K}$ and $\mathrm{Cl}^{-}$, the solubility of the other elements is in general limited by hydroxides, sulphates and carbonates, which are normally dependent on the solution $\mathrm{pH}$.

\subsection{Thermal behaviour}

The knowledge of the thermal behaviour of APC residues may be important for some treatments (sintering, melting and vitrification) or final applications of the waste (ceramic or glassceramic). When the temperature was increased from 20 to $1200^{\circ} \mathrm{C}$, in a rate of $10^{\circ} \mathrm{C} / \mathrm{min}$, the behaviour of two samples of APC residues (A2 and A5) was observed through simultaneous thermal analysis (STA), which is shown in Fig. 11. The thermal gravimetric (TG) analysis measures weight changes in the waste, and when the temperature reached $1200^{\circ} \mathrm{C}$, a loss of $32.2 \%$ (for A2) and $32.8 \%$ (for A5) was detected (TG equal to $67.8 \%$ and $67.2 \%$ represented on left $y$-axis of Fig. 11). Due to the mineralogical complexity of the APC residues, it is not possible to

Table 8

Mineralogical phases in APC residues, and leaching controlling solids

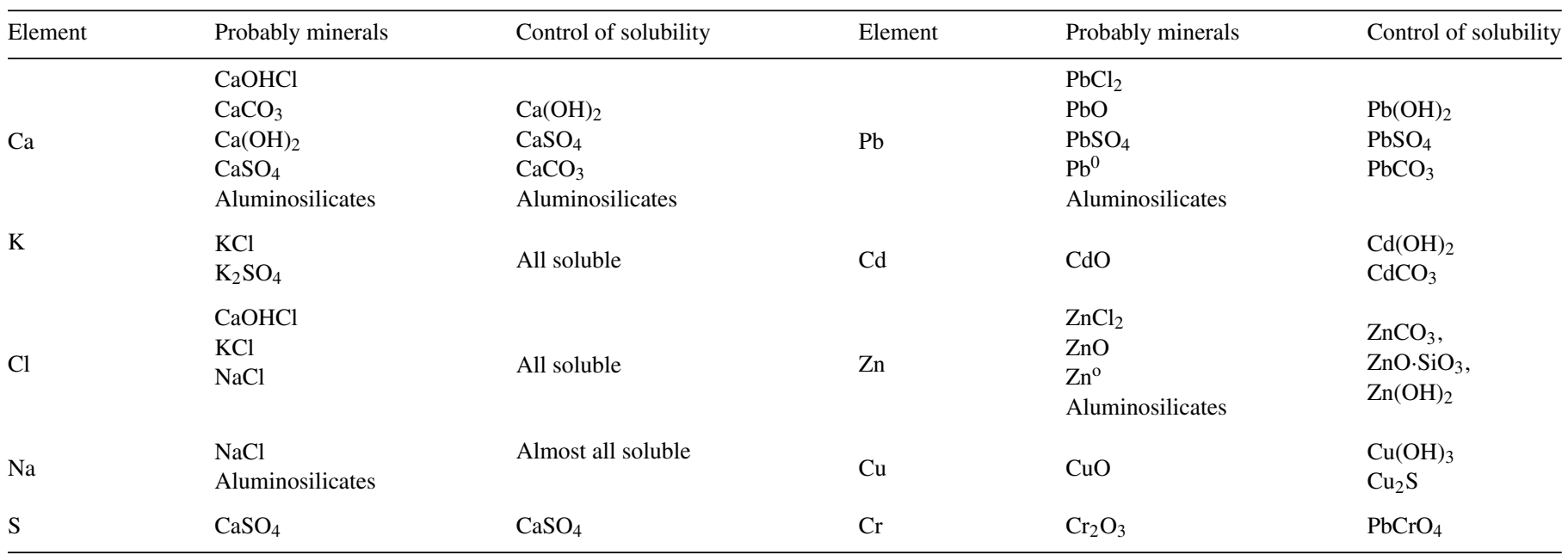




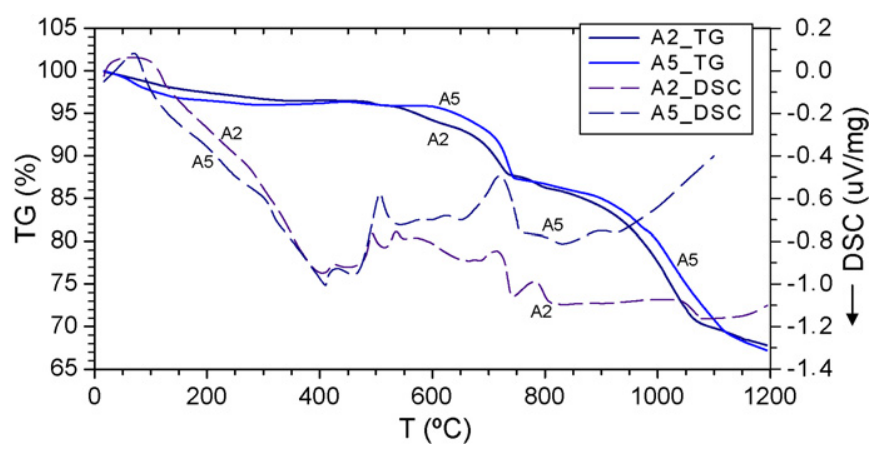

Fig. 11. Simultaneous thermal analysis-STA (TG and DSC) for samples A2 and A5.

interpret all individual energetic events observed in the Differential Scanning Calorimetry (DSC) curves, which are referred to the right $y$-axis. The TG loss of $4 \%$ until $500{ }^{\circ} \mathrm{C}$ corresponds to structural water, oxidation of organic matter (including activated carbon) and to the decomposition of the portlandite (which occurs in the range of $400-450{ }^{\circ} \mathrm{C}$ ). The $\mathrm{Ca}(\mathrm{OH})_{2}$ decomposition may explain the endothermic event observed for both samples (A2 and A5). The significant loss observed when temperature is in the range of $600-750^{\circ} \mathrm{C}$ is mainly due to the decomposition of calcium hydroxychloride and calcite through the following reactions:

$\mathrm{CaOHCl}(\mathrm{s}) \rightarrow \mathrm{CaO}(\mathrm{s})+\mathrm{HCl}(\mathrm{g})$

$\mathrm{CaCO}_{3}(\mathrm{~s}) \rightarrow \mathrm{CaO}(\mathrm{s})+\mathrm{CO}_{2}(\mathrm{~g})$

In fact, both reactions are endothermic, which are in agreement with the DSC curves (endothermic peaks). For higher temperatures than $750^{\circ} \mathrm{C}$ a significant weight loss is again observed, which is probably related with the decomposition of the $\mathrm{NaCl}$ and $\mathrm{KCl}$ phases, with the release of $\mathrm{HCl}$ gas. In Fig. 12 a comparison between the behaviour of the residue before and after washing is presented, being evident that contrarily to the original sample for which the weight loss is about $32.2 \%$, after the APC residues having been in contact with water, only $22.1 \%$ is lost. However, during the washing process the waste lost was about $24.5 \%$ due to solubilization, and adding this quantity to the heating loss of $22.1 \%$, an overall loss of $41 \%$ is then observed.

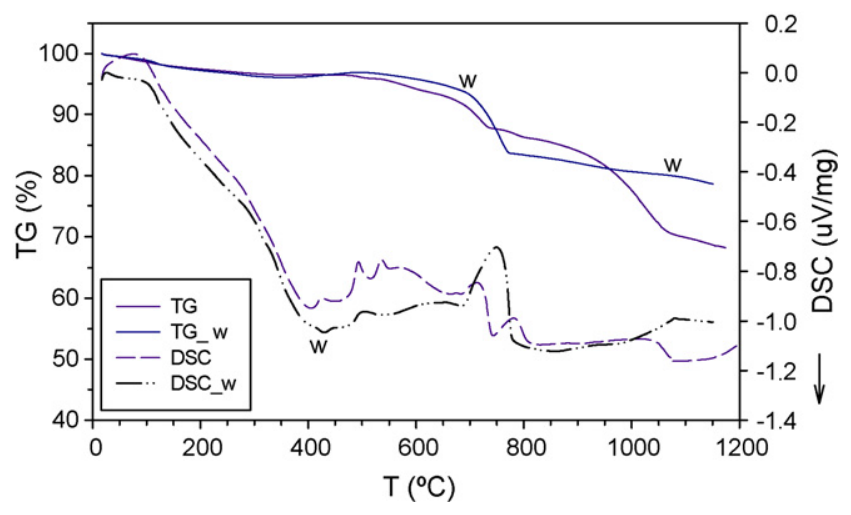

Fig. 12. Simultaneous thermal analysis—STA (TG and DSC) for sample A2 before and after washed (w).
By comparing the curves for unleached and washed residue (w), it is observable that until near $800^{\circ} \mathrm{C}$ the behaviour is similar. For temperatures higher than $800^{\circ} \mathrm{C}$, the leached residue (w) looses a smaller amount of weight. This result is in accordance with the previous conclusion, starting that $\mathrm{NaCl}$ and $\mathrm{KCl}$ were the main phases responsible for that decrease. In fact, taking into account the results of XRD indicated in Fig. 10, it is clear that after washing, the halite $(\mathrm{NaCl})$ and sylvite $(\mathrm{KCl})$ phases are no longer present in the residue. In particular, above $1050^{\circ} \mathrm{C}$ a lower weight loss is observed, which may correspond to some decomposition of phases such as anhydrite $\left(\mathrm{CaSO}_{4}\right)$ and melting of inorganic matter as referred by other authors [83].

\section{Conclusion}

In this context, the main objective of the present work is the characterization of five samples of APC residues collected in an industrial incineration plant located in Portugal for more than 2 years.

The morphological analysis through SEM examination revealed that APC residues is a fine particulate material composed by a broad range of sizes, with rough surfaces as a result of the condensation processes during the decreasing of the gaseous stream temperature. In spite of the complexity of shapes, two types of particles can be observed: spherical particles (constituted by aluminosilicate) and polycrystalline platelets. The mean value for moisture content of those APC residues is about $0.86 \%$, and the loss on ignition (LOI) at $550{ }^{\circ} \mathrm{C}$ revealed a mean weight loss of $1.56 \%$ and around $8.39 \%$ at $750^{\circ} \mathrm{C}$. The distributions of particle size diameters are characterized by mean diameter in the range of $159-244 \mu \mathrm{m}$, and when $1 \mathrm{~min}$ of ultrasonic treatment was used, that parameter decreases to $44-189 \mu \mathrm{m}$. The true density was found to be $2.53 \mathrm{~g} / \mathrm{cm}^{3}$ in average, and the specific surface area is in the range $4.94-6.77 \mathrm{~m}^{2} / \mathrm{g}$.

In terms of chemical characteristics, XRF analysis allowed the identification of 20 elements $(\mathrm{Ca}, \mathrm{Cl}, \mathrm{K}, \mathrm{S}, \mathrm{Fe}, \mathrm{Cr}, \mathrm{Ti}, \mathrm{P}$, $\mathrm{Si}, \mathrm{Al}, \mathrm{Mg}, \mathrm{Na}, \mathrm{Cu}, \mathrm{Zn}, \mathrm{Ba}, \mathrm{Sn}, \mathrm{Sb}, \mathrm{Sr}, \mathrm{Br}$ and $\mathrm{Pb}$ ), and additionally through acid digestions followed by FAAS, also $\mathrm{Cd}$ and $\mathrm{Ni}$ were detected, while by amalgamation $\mathrm{Hg}$ was identified as well. In general, digestion with aqua regia leads to more reliable results in what respects $\mathrm{Pb}, \mathrm{Cd}, \mathrm{Zn}, \mathrm{Cr}, \mathrm{Ni}, \mathrm{Cu}, \mathrm{K}, \mathrm{Na}$, $\mathrm{Ca}, \mathrm{Fe}$ and $\mathrm{Al}$. Only Si requires digestion with $\mathrm{HF}$ acid. The carbon content is $2.8-6.55 \%$, and about $35.6 \%$ of the total carbon may be from organic compounds whereas $64.4 \%$ is due to inorganic forms (carbonates). However, only $0.4 \%$ of the carbon can be dissolved in water. The released quantity under aggressive condition (NEN 7341) depend on the element: almost all $\mathrm{Na}, \mathrm{K}, \mathrm{Cl}$ is released, near $90 \%$ of $\mathrm{Cd}, 40-50 \%$ of the $\mathrm{Zn}$ and $\mathrm{Cu}, 15-20 \%$ of $\mathrm{Cr}$ and $\mathrm{Ni}$, and very low quantities of $\mathrm{Al}, \mathrm{Fe}$ and $\mathrm{Si}$. The availability test fails for $\mathrm{Pb}(6 \%)$, since a higher amount is released (near 20\%) when the residue is in contact with water. This behaviour results from the amphoteric characteristics of this element. Several compliance tests (DIN 38414-S4, TCLP, AFNOR X 31-210) have revealed that the main problem of the APC residues is related with the high released amount of $\mathrm{Pb}$, as well as with the high amount of soluble salts (TDS). 
The mineralogical phase identified by XRD were halite $(\mathrm{NaCl})$, sylvite $(\mathrm{KCl})$, calcite $\left(\mathrm{CaCO}_{3}\right)$, anhyidrite $\left(\mathrm{CaSO}_{4}\right)$, quartz $\left(\mathrm{SiO}_{2}\right)$, gehlenite $\left(\mathrm{Ca}_{2} \mathrm{Al}\left(\mathrm{AlSiO}_{7}\right)\right)$, hematite $\left(\mathrm{Fe}_{2} \mathrm{O}_{3}\right)$, portlandite $\left(\mathrm{Ca}(\mathrm{OH})_{2}\right)$ and calcium hydroxychloride $(\mathrm{CaOHCl})$. When the residue contacted with water, the main solubilized phases were $\mathrm{NaCl}, \mathrm{KCl}$ and $\mathrm{CaOHCl}$. Thermal analysis showed that when the temperature increases to $1200^{\circ} \mathrm{C}$, the weight loss is near $32 \%$, and if the residue is previously washed that amount decreases to $22 \%$. The weight loss corresponds mainly to the thermal decomposition of organic compounds, activated carbon, $\mathrm{Ca}(\mathrm{OH})_{2}, \mathrm{CaCO}_{3}, \mathrm{CaOHCl}, \mathrm{NaCl}$ and $\mathrm{KCl}$.

\section{Acknowledgement}

Centro Tecnológico da Cerâmica e do Vidro (CTCV) is acknowledged for their assistance with some of analytical work.

\section{References}

[1] IAWG (International Ash Working Group: A.J. Chandler, T.T. Eighmy, O. Hartlén, D. Kosson, S.E. Sawell, H. van der Sloot, J. Vehlow) Municipal Solid Waste Incinerator Residues, Studies in Environmental Science, vol. 67, Elsevier Science, Amsterdam, 1997.

[2] A.J. Pedersen, L.M. Ottosen, A. Villumsen, Electrodialytic removal of heavy metals from municipal solid waste incineration fly ash using ammonium citrate as assisting agent, J. Hazard. Mater. 122 (1/2) (2005) 103-109.

[3] W. Krebs, R. Bachofen, H. Brandl, Growth stimulation of sulfur oxidizing bacteria for optimization of metal leaching efficiency of fly ash from municipal solid waste incineration, Hydrometallurgy 59 (2/3) (2001) 283-290.

[4] K.J.Hong, S. Tokunaga, T. Kajiuchi, Extraction of heavy metals from MSW incinerator fly ashes by chelating agents, J. Hazard. Mater. 75 (1) (2000) 57-73.

[5] S. Nagib, K. Inoue, Recovery of lead and zinc from fly ash generated from municipal incineration plants by means of acid and/or alkaline leaching, Hydrometallurgy 56 (3) (2000) 269-292.

[6] P.O. Auer, B. Eichler, C. Ludwing, S. Stucki, J. Wochele, Recycling heavy metals by the method of fractionated condensation, in: 4th World Congress-Recovery, Recycling, Re-integration, vol. IV, Geneve, 1999, pp. 328-333.

[7] H. Katsuura, T. Inoue, M. Hiraoka, S. Sakai, Full-scale plant study on fly ash treatment by the acid extraction process, Waste Manage. 16 (5/6) (1996) 491-499.

[8] D. Geysen, K. Imbrechts, C. Vandecasteele, M. Jaspers, G. Wauters, Immobilization of lead and zinc in scrubber residues from MSW combustion using soluble phosphates, Waste Manage. 24 (5) (2004) 471-481.

[9] D. Geysen, C. Vandecasteele, M. Jaspers, G. Wauters, Comparison of immobilisation of air pollution control residues with cement and with silica, J. Hazard. Mater. 107 (3) (2004) 131-143

[10] K. Lundtorp, D.L. Jensen, M.A. Sorensen, T.H. Christensen, E.P.B. Mogensen, Treatment of waste incinerator air-pollution-control residues with $\mathrm{FeSO}_{4}$ : concept and product characterisation, Waste Manage. Res. 20 (2002) 69-79.

[11] N. Alba, E. Vázquez, S. Gassó, J.M. Baldasano, Stabilization/solidification of MSW incineration residues from facilities with different air pollution control systems. Durability of matrices versus carbonation, Waste Manage. 21 (4) (2001) 313-323.

[12] T. Mangialardi, A.E. Paolini, A. Polettini, P. Sirini, Optimization of the solidification/stabilization process of MSW fly ash in cementitious matrices, J. Hazard. Mater. 70 (1/2) (1999) 53-70.

[13] T.T. Eighmy, B.S. Crannell, L.G. Butler, F.K. Cartledge, E.F. Emery, D. Oblas, J.E. Krzanowski, J.D. Eusden, E.L. Shaw, C.A. Francis, Heavy metal stabilization in municipal solid waste combustion dry scrubber residue using soluble phosphate, Environ. Sci. Technol. 33 (11) (1997) 3330-3338.
[14] C.H. Jung, T. Matsuto, N. Tanaka, Behavior of metals in ash melting and gasification-melting of municipal solid waste (MSW), Waste Manage. 25 (3) (2005) 301-310.

[15] Y.-M. Kuo, T.-C. Lin, P.-J. Tsai, Metal behavior during vitrification of incinerator ash in a coke bed furnace, J. Hazard. Mater. 109 (1-3) (2004) 79-84.

[16] Y.J. Park, J. Heo, Vitrification of fly ash from municipal solid waste incinerator, J. Hazard. Mater. B 91 (2002) 83-93.

[17] D.W. Kirk, C.C. Chan, H. Marsh, Chromium behavior during thermal treatment of MSW fly ash, J. Hazard. Mater. 90 (1) (2002) 39-49.

[18] S. Sakai, M. Hiraoka, Municipal solid waste incinerator residue recycling by thermal processes, Waste Manage. 20 (2/3) (2000) 249-258.

[19] T. Mangialardi, Disposal of MSWI fly ash through a combined washingimmobilisation process, J. Hazard. Mater. 98 (1-3) (2003) 225-240.

[20] A. Nzihou, P. Sharrock, Calcium phosphate stabilization of fly ash with chloride extraction, Waste Manage. 22 (2) (2002) 235-239.

[21] M.A. Sorensen, E.P. Mogensen, K. Lundtorp, D.L. Jensen, T.H. Christensen, High temperature co-treatment of bottom ash and stabilized fly ashes from waste incineration, Waste Manage. 21 (6) (2001) 555-562.

[22] G. Qian, Y. Cao, P. Chui, J. Tay, Utilization of MSWI fly ash for stabilization/solidification of industrial waste sludge, J. Hazard. Mater. 129 (1-3) (2006) 274-281

[23] G. Qian, Y. Song, C. Zhang, Y. Xia, H. Zhang, P. Chui, Diopside-based glass-ceramics from MSW fly ash and bottom ash, Waste Manage. 26 (12) (2006) 1462-1467.

[24] Z. Cai, D.H. Bager, T.H. Christensen, Leaching from solid waste incineration ashes used in cement-treated base layers for pavements, Waste Manage. 24 (6) (2004) 603-612.

[25] M.J. Quina, M.A. Almeida, R. Santos, J.M. Bordado, R.M. Quinta Ferreira, Utilisation of a waste for producing lightweight aggregates, in: S. Sebastian (Ed.), Proceedings of the WASCON'2003, 2003, pp. 925-928.

[26] Y.J. Park, J. Heo, Conversion to glass-ceramics from glasses made by MSW incinerator fly ash for recycling, Ceram. Int. 28 (6) (2002) 689-694.

[27] K.O. Ampadu, K. Torii, Characterization of ecocement pastes and mortars produced from incinerated ashes, Cem. Concr. Res. 31 (2001) 431-436.

[28] T. Mangialardi, Sintering of MSW fly ash for reuse as a concrete aggregate, J. Hazard. Mater. 87 (1-3) (2001) 225-239.

[29] S.E. Sawell, A.J. Chandler, T.T. Eighmy, D. Kosson, H.A. van der Sloot, J. Hartlén, O. Hjelmar, J. Vehlow, An international perspective on the characterisation and management of residues from MSW incinerators, Biomass Bioenergy 9 (1-5) (1995) 377-386.

[30] N. Saikia, S. Kato, T. Kojima, Compositions and leaching behaviours of combustion residues, Fuel 85 (2006) 264-271.

[31] H. Hwang, C.U. Ro, Single-particle characterization of municipal solid waste (MSW) ash particles using low-Z particle electron probe X-ray microanalysis, Atmos. Environ. 40 (2006) 2873-2881.

[32] P.-J. He, H. Zhang, C.-G. Zhang, D.-J. Lee, Characteristics of air pollution control residues of MSW incineration plant in Shanghai, J. Hazard. Mater. 116 (3) (2004) 229-237.

[33] G.J. Song, K. Kim, Y. Seo, S. Kim, Characteristics of ashes from different locations at the MSW incinerator equipped with various air pollution control devices, Waste Manage. 24 (2004) 99-106.

[34] M. Li, J. Xiang, S. Hu, L.-S. Sun, S. Su, P.-S. Li, X.-X. Sun, Characterization of solid residues from municipal solid waste incinerator, Fuel 83 (10) (2004) 1397-1405.

[35] M. Li, S. Hu, J. Xiang, L.-S. Sun, P.-S. Li, S. Su, X.-X. Sun, Characterization of fly ashes from two Chinese municipal solid waste incinerators, Energy Fuels 17 (6) (2003) 1487-1491.

[36] F. Bodénan, P. Deniard, Characterization of flue gas cleaning residues from European solid waste incinerators: assessment of various Ca-based sorbent processes, Chemosphere 51 (5) (2003) 335-347.

[37] H.A. van der Sloot, D.S. Kosson, O. Hjelmar, Characteristics, treatment and utilization of residues from municipal waste incineration, Waste Manage. 21 (8) (2001) 753-765.

[38] M.B. Chang, C.K. Huang, H.T. Wu, J.J. Lin, S.H. Chang, Characteristics of heavy metals on particles with different sizes from municipal solid waste incineration, J. Hazard. Mater. 79 (3) (2000) 229-239. 
[39] R. Ibánez, A. Andrés, J.R. Viguri, I. Ortiz, J.A. Irabien, Characterisation and Management of Incinerator Wastes, J. Hazard. Mater. A 79 (2000) 215-227.

[40] L. Le Forestier, G. Libourel, Characterization of flue gas residues from municipal solid waste combustors, Environ. Sci. Technol. 32 (15) (1998) 2250-2256.

[41] M. Tettamanti, E. Collina, M. Lasagni, D. Pitea, D. Grasso, C. La Rosa, Characterization of fly ash from municipal solid waste incinerators using differential scanning calorimetry, Thermochim. Acta 321 (1/2) (1998) 133-141.

[42] N. Alba, S. Gasso, T. Lacorte, J.M. Baldasano, Characterization of municipal solid waste incineration residues from facilities with different air pollution control systems, J. Air Waste Manage. Assoc. 47 (11) (1997) $1170-1179$.

[43] A. Åberg, J. Kumpiene, H. Ecke, Evaluation and prediction of emissions from a road built with bottom ash from municipal solid waste incineration (MSWI), Sci. Total Environ. 355 (1-3) (2006) 1-12.

[44] C.R. Cheeseman, A. Makinde, S. Bethanis, Properties of lightweight aggregate produced by rapid sintering of incinerator bottom ash, Resourc. Conserv. Recycling 43 (2) (2005) 147-162.

[45] S. Bethanis, C.R. Cheeseman, C.J. Sollars, Properties and microstructure of sintered incinerator bottom ash, Ceram. Int. 28 (2002) 881-886.

[46] B.S. Crannell, T.T. Eighmy, J.E. Krzanowski, J.D. Eusden Jr., E.L. Shaw, C.A. Francis, Heavy metal stabilization in municipal solid waste combustion bottom ash using soluble phosphate, Waste Manage. 20 (2/3) (2000) $135-148$.

[47] J.M. Chimenos, M. Segarra, M.A. Fernández, F. Espiell, Characterization of the bottom ash in municipal solid waste incinerator, J. Hazard. Mater. A 64 (1999) 211-222.

[48] S. Dugenest, J. Combrisson, H. Casabianca, M. Loustalot, Municipal solid waste incineration bottom ash: characterization and kinetic studies of organic matter, Environ. Sci. Technol. 33 (7) (1999) 1110-1115.

[49] M. Lemann, R. Walder, A. Schwyn, Heavy metals in municipal solid waste incineration residues, J. Power Sources 57 (1/2) (1995) 55-59.

[50] C. Kirby, J. Rimstidt, Mineralogy and surface properties of municipal solid waste ash, Environ. Sci. Technol. 27 (4) (1993) 652-660.

[51] T.T. Eighmy, J. Eusden, J. Krzanowski, D. Domingo, D. Stampfli, J. Martin, P. Erickson, Comprehensive approach toward understanding element speciation and leaching behavior in municipal solid waste incineration electrostatic precipitator ash, Environ. Sci. Technol. 29 (3) (1995) 629-646.

[52] D. Geysen, C. Vandecasteele, M. Jaspers, E. Brouwers, G. Wauters, Effect of improving flue gas cleaning on characteristics and immobilisation of APC residues from MSW incineration, J. Hazard. Mater. 128 (1) (2006) 27-38.

[53] X. Wan, W. Wang, T. Ye, Y. Guo, X. Gao, A study on the chemical and mineralogical characterization of MSWI fly ash using a sequential extraction procedure, J. Hazard. Mater. 134 (1-3) (2006) 197-201.

[54] S.S. Thipse, M. Schoenitz, E.L. Dreizin, Morphology and composition of the fly ash particles produced in incineration of municipal solid waste, Fuel Process. Technol. 75 (3) (2002) 173-184.

[55] P. Van Herck, B. Van der Bruggen, G. Vogels, C. Vandecasteele, Evaluation of the use of a sequential extraction procedure for the characterization and treatment of metal containing solid waste, Waste Manage. 21 (8) (2001) 685-694.

[56] W. Xie, Y. Xie, W.-P. Pan, A. Riga, Characterization of the ash deposits from AFBC system using thermal techniques, Thermochim. Acta 357/358 (2000) 231-238.

[57] A.M. Fallman, Performance and design of the availability test for measurement of potentially leachable amounts from waste materials, Environ. Sci. Technol. 31 (3) (1997) 735-744.

[58] S. Stucki, A. Jakob, Thermal treatment of incinerator fly ash: factors influencing the evaporation of $\mathrm{ZnCl}_{2}$, Waste Manage. 17 (4) (1997) 231-236.

[59] S. Iretskaya, A. Nzihou, C. Zahraoui, P. Sharrock, Metal leaching from MSW fly ash before and after chemical and thermal treatments, Environ. Prog. 18 (2) (1999) 144-148.

[60] A. Jakob, S. Stucki, P. Kuhn, Evaporation of heavy metals during the heat treatment of municipal solid waste incinerator fly ash, Environ. Sci. Technol. 29 (9) (1995) 2429-2436.
[61] S. Mizutani, T. Yoshida, S. Sakai, H. Takatsuki, Release of metals from MSW I fly ash and availability in alkali condition, Waste Manage. 16 (5/6) (1996) 537-544.

[62] T. Sabbas, A. Polettini, R. Pomi, T. Astrup, O. Hjelmar, P. Mostbauer, G. Cappai, G. Magel, S. Salhofer, C. Speiser, S. Heuss-Assbichler, R. Klein, P. Lechber, Management of municipal solid waste incineration residues, Waste Manage. 23 (1) (2003) 61-88.

[63] Z. Mester, M. Angelone, C. Brunori, C. Cremisini, H. Muntau, R. Morabito, Digestion methods for analysis of fly ash samples by atomic absorption spectrometry, Anal. Chim. Acta 395 (1/2) (1999) 157-163.

[64] S. Auer, H.-J. Kuzel, H. Pollmann, F. Sorrentino, Investigation on MSW fly ash treatment by reactive calcium aluminates and phases formed, Cem. Concr. Res. 25 (6) (1995) 1347-1359.

[65] M. Kersten, B. Schulz-Dobrick, T. Lichtensteiger, C.A. Johnson, Speciation of $\mathrm{Cr}$ in leachates of a MSWI bottom ash landfill, Environ. Sci. Technol. 32 (10) (1998) 1398-1403.

[66] A. Kida, Y. Noma, T. Imada, Chemical speciation and leaching properties of elements in municipal incinerator ashes, Waste Manage. 16 (5/6) (1996) 527-536.

[67] P. Piantone, F. Bodénan, R. Derie, G. Depelsenaire, Monitoring the stabilization of municipal solid waste incineration fly ash by phosphation: mineralogical and balance approach, Waste Manage. 23 (3) (2003) 225-243.

[68] M.A. Sorensen, C.B. Koch, M.M. Stackpoole, R.K. Bordia, M.M. Benjamin, T.H. Christensen, Effects of thermal treatment on mineralogy and heavy metal behavior in iron oxide stabilized air pollution control residues, Environ. Sci. Technol. 34 (21) (2000) 4620-4627.

[69] M.K. Cieplik, V. De Jong, J. Bozovic, P. Liljelind, S. Marklund, R. Louw, Formation of dioxins from combustion micropollutants over MSWI fly ash, Environ. Sci. Technol. 40 (4) (2006) 1263-1269.

[70] G. McKay, Dioxin characterisation, formation and minimisation during municipal solid waste (MSW) incineration: review, Chem. Eng. J. 86 (2002) 343-368.

[71] E. Abad, J. Caixach, J. Rivera, Improvements in dioxin abatement strategies at a municipal waste management plant in Barcelona, Chemosphere 50 (9) (2003) 1175-1182.

[72] E. Abad, M.A. Andrados, J. Caixach, J. Rivera, Dioxin abatement strategies and mass balance at a municipal waste management plant, Environ. Sci. Technol. 36 (1) (2002) 92-99.

[73] R. Addink, H. Govers, K. Olie, Isomer distribution of polichlorinated dibenzo- $p$-dioxins/dibenzofurans formed during de novo synthesis on incinerator fly ash, Environ. Sci. Technol. 32 (13) (1998) 1888-1893.

[74] A. Buekens, H. Huang, Comparative evaluation of techniques for controlling the formation and emission of chlorinated dioxins/furans in municipal waste incineration, J. Hazard. Mater. 62 (1) (1998) 1-33.

[75] L.S. Morf, P.H. Brunner, S. Spaun, Effect of operating conditions and input variations on the partitioning of metals in a municipal solid waste incinerator, Waste Manage. Res. 18 (1) (2000) 4-15.

[76] M.-Y. Wey, J.-L. Su, M.-H. Yan, M.-C. Wei, The concentration distribution of heavy metals under different incineration operation conditions, Sci. Total Environ. 212 (2/3) (1998) 183-193.

[77] H.A. van der Sloot, L. Heasman, Ph. Quevauviller, Harmonization of Leaching Extraction Tests, Studies in Environmental Science, vol. 70, Elsevier Science, Amsterdam, 1997.

[78] P.-J. He, Q.-K. Cao, L.-M. Shao, D.-J. Lee, Aging of air pollution contro residues from municipal solid waste incinerator: Role of water content on metal carbonation, Sci. Total Environ. 359 (1-3) (2006) 26-37.

[79] Eurachem/Citac Guide, Quantifying Uncertainty in Analytical Measurement, 2nd ed., 2000.

[80] S. Ferrari, H. Belevi, P. Baccini, Chemical speciation of carbon in municipal solid waste incinerator residues, Waste Manage. 22 (2002) 303-314.

[81] Z. Abbas, A.P. Moghaddam, B.-M. Steenari, Release of salts from municipal solid waste combustion residues, Waste Manage. 23 (4) (2003) 291-305.

[82] S.V. Vassilev, C. Braekman-Danheuxb, Ph. Laurent, T. Thiemann, A. Fontana, Behaviour, capture and inertization of some trace elements during combustion of refuse-derived char from municipal solid waste, Fuel 78 (1999) 1131-1145. 
[83] S. Vassilev, C. Braekman-Danheux, P. Laurent, Characterization of refuse-derived char from municipal solid waste: 1. Phase-mineral and chemical composition, Fuel Process. Technol. 59 (1999) 95134.
[84] S.V. Vassilev, C. Braekman-Danheux, Characterization of refuse-derived char from municipal solid waste 2. Occurrence, abundance and source of trace elements, Fuel Process. Technol. 59 (1999) 135161. 